\title{
LONG-TERM INTERACTIONS OF CLIMATE, PRODUCTIVITY, SPECIES RICHNESS, AND GROWTH FORM IN RELICTUAL SAGEBRUSH STEPPE PLANT COMMUNITIES
}

\author{
Neil E. West ${ }^{1,2}$ and Terence P. Yorks ${ }^{1}$
}

\begin{abstract}
AвstRact.-Vegetation trends due to climatic changes are difficult to separate from disturbances caused by varying land uses. To separate climatic influences from livestock grazing and fire disturbances within sagebrush steppe, we compared vegetation structure and productivity during 2 periods (10-year sequences of data from the late 1950s to the late 1960s and 3 years in the early 1990s) at 12 stands within 3 relict areas in or near the Great Rift of southern Idaho. Yearto-year fluctuations in annual net aboveground phytomass accumulation (ANAPA) were considerable in response to varying climate during both periods. More importantly, an apparently significant increase in ANAPA was observed during the latter study period. However, this apparent increase may have been due to the unusually wet conditions of 1993. Throughout both study periods, ANAPA was even more positively correlated with species richness than with precipitation, although both influences were statistically significant. Aggregation of these data by plant growth forms showed that shrubs, particularly sagebrushes, have progressively increased their proportion relative to herbaceous understory. This directional (successional) change in the proportional contributions of growth forms to ANAPA was probably due more to long-term absence of fire at these isolated locations than to any detectable climate change or lack of grazing. This finding reduces our confidence in the use of such areas as reference sites for monitoring or as living examples for restoration efforts, but it does increase our understanding of vegetation dynamics within sagebrush steppe.
\end{abstract}

Key words: Artemisia tridentata, Artemisia tripartita, bunchgrasses, succession, fluctuations, climax, reference conditions, Idaho, kipukas.

ACRONYMS.—ANAPA—annual net aboveground phytomass accumulations, ANOVA—analysis of variance, ANPPaboveground net primary production, $\mathrm{COV}$ - coefficient of variation, $\mathrm{CY}$ — crop year, $\mathrm{CYP}$ - crop-year precipitation, ES-ecological site, MANOVA-multivariate analysis of variance, MAT-mean annual temperature, NRCS-Natural Resources Conservation Service, PDSI-Palmer Drought Severity Index, RUE_rainfall use efficiency.

A major focus of contemporary plant ecological research is how vegetation responds to global environmental change. This topic can be approached through theory development, modelling, forward-looking and carefully designed experiments, or case studies involving retrospective analyses. All these approaches have their own strengths and shortcomings (Ford 2000) and are complementary (Archer and Bowman 2002).

Because sustained funding for following long-term changes is difficult to obtain, ecologists frequently depend on space-for-time substitutions or short sequences of experimental or observational (i.e., monitoring) data. Deducting cause-effect relationships from these types of data is problematic because "treatments" are restricted to a single or a few factors, replications are limited, and holding variables constant is difficult (Pickett 1989). In areas where growth rates are slow and longevities of dominant organisms extend beyond a few years, it may be impossible to gain definitive results from short-term, forward-looking experiments. This problem is particularly troublesome where self-sown plant communities have multiple growth forms in temperate semiarid environments (Wiegand and Milton 1996). Sagebrush steppe (West 1983, 1999, 2000, West and Young 2000) is one such plant community type that has multiple growth forms dominating within late seral states. Naeem (2001) labels such systems, which are species poor but structurally and functionally diverse, as "complex."

Sagebrush steppe has occupied about 45 million ha of semiarid lowlands of the northern Intermountain Region (West 1983). The

\footnotetext{
${ }^{1}$ Department of Wildland Resources, Utah State University, Logan, UT 84322-5230.

2E-mail: new369@cc.usu.edu
} 
existence of this vegetation type is thought to be primarily due to its geographic position between grassland and desert regions. Both shrubs and herbs have persisted in that zone primarily because vacillations of climate between years of desertic or grassland character have averaged out as semiarid (Cook and Irwin 1992). Most precipitation falling on sagebrush steppe in the past occurred during the winter as snow, which melted slowly (West 1983).

Shifts toward increased temperatures and toward precipitation that comes more often as winter rain than as snow are expected in the Intermountain Region (Giorgi et al. 1994, Ferguson 1997, Smith et al. 2001, Wagner 2003). An extended spring-summer-fall fire season along with a decreased fire-return interval (Ryan 1991, McKenzie et al. 2004) would likely favor herbs over nonsprouting shrubs such as most sagebrushes. Further aridization is expected by some (Lauenroth et al. 2004), and would also favor that scenario.

Even without climate change, the net impact of vegetation changes has already been severe for animals of sagebrush steppes (Wisdom et al. 2005, Welch 2005). Rates of listings and proposed listings under the Endangered Species Act have been accelerating. During the 20th century, large fractions of sagebrush steppe were converted to farms, towns, and the infrastructure connecting modern human activity (West 2000, Bunting et al. 2002, Wisdom et al. 2005, Welch 2005). Even the remaining unroaded or unplowed portions of sagebrush steppe have been changed, primarily because of livestock grazing, altered fire regimes, and invasion of exotics (Miller et al. 1994). Changes in the soils of sagebrush steppe (Norton et al. 2004) and their erosion and hydrologic regimes are also of concern.

Private and governmental land managers were intentionally reducing sagebrush abundance in the post-World War II era to enhance production of red meat (West 1983). Federal policies have slowly moved towards generally favoring attempts to prevent further loss of sagebrush and implementing programs to reestablish sagebrush and associated native perennial forbs and grasses where they have been previously reduced or eliminated (BLM 2002, Welch 2005). These efforts could be enhanced with better knowledge of both the fluctuational (nondirectional) and successional (directional) dynamics (Rabotnov 1974) of sagebrush steppe plant communities. Recovery of sagebrush steppes after the exclusion or reduction of livestock use over the past several decades has been studied extensively (e.g., Anderson and Inouye 2001). Analysis of fluctuations, apart from secondary succession following disturbance, however, ideally requires availability of areas that have remained without disturbance (relicts; Clements 1934), at least from livestock grazing. It is also under these rarer circumstances that we have a chance of separating fluctuations from any longer term (successional) shifts in this vegetation due to possible climatic change. Such understanding is important if relictual systems are used as reference conditions for monitoring changes (Rowlands and Brian 2001) or designing restoration efforts (e.g., Hockett 2002) on similar ecological sites (Creque et al. 1999).

\section{ObJECTIVES}

We took advantage of an opportunity to pursue the following objectives:

(1) Reexamine the temporal variations in annual net aboveground phytomass accumulations (ANAPA) in relation to variations in climate, species richness, and relative abundance of growth forms at 13 stands within 4 relict areas in southern Idaho. Ten years of annual data were collected during the late 1950s to the late 1960s by Passey et al. (1982). Hereafter, mention of this study will not include the year of publication.

(2) Reexamine ANAPA in relation to climate, species richness, and growth form contributions for the 12 remaining stands within 3 relict areas during the early 1990s using data collected by Hosten (1995). Hereafter, mention of this study will not include the year of publication.

(3) Compare the differences between these 2 data sets and relate them to the limited instrumental and modeled climatic trends, or other possible differences in environment during and between the 2 sampling intervals, i.e., about 30 years apart.

Both Passey et al. and Hosten focused their analyses and discussions at the species level, stand level, or overall level, but generally avoided aggregating their data by relict area, as we will do. Our null hypotheses, largely based on results of Passey et al., were (1) that 
ANAPAs of vegetation on never-grazed relicts would fluctuate in relation to year-to-year or longer spans of climatic variation, but (2) would be successionally stable, showing little longterm change in species composition or proportions between growth forms primarily because of lack of livestock grazing-a disturbance agent pervasive nearly everywhere else within this ecosystem type (Miller et al. 1994).

\section{Methods}

Passey et al. studied the vegetation and soils at 85 locations within the lowlands of the Intermountain West, which shared sagebrush and bunchgrass dominance during the 1950s and 1960s. Most of their data were 1-time samples. Of particular interest to us, however, were their "repeat" studies: 10-year sequences of ANAPA data from 13 stands at selected locations within 4 relict areas (never grazed by livestock) on kipukas (elevated, older pieces of landscape with developed soil surrounded by younger lava flows at slightly lower elevations; Tisdale et al. 1965) within the Great Rift of the Central Snake River Plains, southern Idaho. The geologically recent, usually rugose outpourings of lava surrounding the kipukas have created natural exclosures to large, hoofed animals. Detailed descriptions of the topographic, geologic, and edaphic features of these areas can be found in Passey et al. (1982).

Of greatest interest to us were details of the Passey et al. vegetation data. Aboveground standing crop was measured once per year at the end of the growing season (late June to early July). These data were recorded from a set of twenty $0.89-\mathrm{m}^{2}$ circular plots randomly scattered within each selected stand. Whereas all the Passey et al. data we reanalyzed involved 10-year time series, beginnings and endings of data sequences for particular stands varied 1 or 2 years between 1958 and 1969 . The 2 rightmost digits of the site numbers in column 1 of Table 1 indicate the year that data collection began at that stand $(1958,1959$, or 1960).

Late June to early July is good timing for capturing data on probable maximal yearly standing crops of the new aboveground plant tissue produced that year, because most plant growth in this cool, temperate, but semiarid climate takes place in spring (May-June), and is truncated during the typical drought period of middle to late summer when temperatures rise and soil moisture is depleted (West 1983, Anderson and Inouye 2001). These midsummer standing crops of plant tissue produced during each growing season (ANAPA) can be regarded as a conservative estimate of aboveground net primary production (ANPP) in this ecosystem type (Pearson 1965, 1966). ANAPA is a conservative proxy for ANPP for several reasons. First, already dried and shattered small, pre-vernal and vernal species are probably missed (Pokorny et al. 2004). Second, some later vegetative growth of shrubs is definitely missed. Third, the flowering and fruiting portions of Artemisia and Chrysothamnus are routinely missed because these shrubs flower and fruit several months later. Fourth, early fall regreening of perennial grasses and Bromus tectorum seedlings are also missed when substantial August-September precipitation occurs. Because these and other possible contributions to ANPP were not recorded, we use the descriptor ANAPA instead.

We possess the original field data of Passey et al. (1982: exhibit 2) and therefore know that ANAPA was not recorded individually for all plant species encountered. Passey et al. lumped some species with minor amounts of new plant growth into aggregate categories (e.g., "other shrubs," 0.04 mean percent of total shrub ANAPA; "other grasses," 0.2 mean percent of total grass ANAPA; "other forbs," 14 mean percent of total forb ANAPA; and "other annuals," 29 mean percent of ANAPA ascribed to annuals). They did, however, separately distinguish dominant natives and the important introduced annual grass Bromus tectorum (Billings 1994). Their choice to simplify these field procedures complicates how some issues of community biodiversity (particularly richness and evenness) are addressed and casts doubt on results from some procedures sensitive to incomplete data (e.g., ordination). Accordingly, we were forced to use the conservative numbers of Passey et al. when relating total vascular plant species richness to total ANAPA, species compositional turnover, and successional trends.

We thought it reasonable to place all species contributing to the ANAPA data into growth form categories: shrubs, perennial grasses, perennial forbs, annual grasses, or annual forbs. So few species contributed to some possible categories, however, that we have combined some groupings for graphical purposes. For 


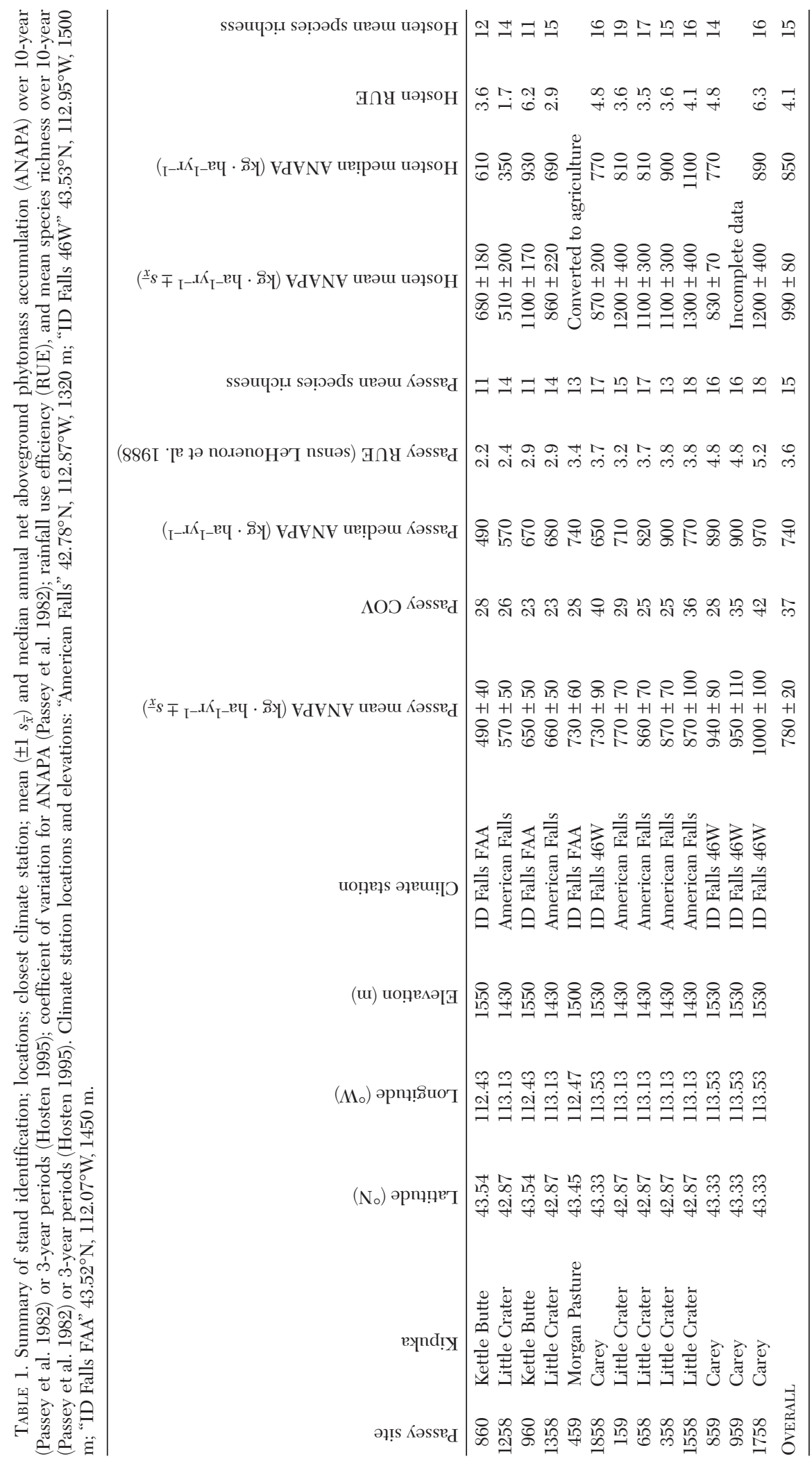


instance, the single succulent encountered, Opuntia polycantha, was a minor contributor to ANAPA and was included in the shrub category. Placements of species within growth form categories, designations of "native" or "introduced," and common and Latin names were derived from the Plants and Life History Database (available from: http://plants.usda.gov). We created a cross-referenced table to relate the plant names used by both Passey et al. and Hosten to the "Plants" database.

Passey et al. made their first year's ANAPA data collection by clustering three $0.89-\mathrm{m}^{2}$ plots to be clipped near the center of the selected stands, in a spot visually regarded as representing the average for that stand. The ANAPAs of individual major species and aggregate weights of standing dead phytomass and litter were estimated in those 3 quadrats, as well as in 20 additional marked quadrats randomly located within the stand. Clippings from the 3 harvested plots were weighed when fresh and again after air drying. This double sampling (Bonham 1989) allowed Passey et al. to quantify relationships between estimated weights, measured weights, and dried weights. The resulting regression coefficients were then applied to the 20 estimated, but unclipped plots to calculate ANAPA. During subsequent years, Passey et al. simply chose the previously marked 20 randomly placed plots within the stand and clipped 3. The clipped plots were avoided during subsequent years, and 3 additional random locations had to be added each year to keep the annual sample size within each stand at 20 plots.

Hosten altered the above procedure to improve the regressions by choosing 3 plots each year that were judged to have the highest, median, and lowest new growth phytomass, respectively. These plots were scattered throughout each stand. Hosten avoided aggregate categories such as "other minor forbs" by identifying the current year's growth of all species. Phytomass due to current year's growth on the other 17 marked, randomly located plots in each stand were visually estimated by Hosten following calibration from the clipped plots, again using double sampling (Bonham 1989). Hosten calibrated the unclipped estimates for the same sites based on oven-dry weights. This resulted in phytomass values that were slightly, but consistently less than those reported by Passey et al. The cumulative area sampled each year in each stand during both sampling periods was $17.8 \mathrm{~m}^{2}$.

In addition to the ANAPA data, both Passey et al. and Hosten recorded data on densities, maturity classes, and foliage densities of shrubs within a belt transect, $1.5 \mathrm{~m}$ wide and $61 \mathrm{~m}$ long, centered over the middle of each stand at the beginning of the 2 study periods. Hosten determined where the Passey et al. transect had been by locating depressions and adjacent mounds of soil where Passey et al. had dug their soil pits and then incompletely filled them. All woody species within these long narrow plots were counted and ascribed to 1 of 5 maturity state classes (seedling, immature, mature, partly dead, and completely dead). These maturity state class data were reduced to proportions to allow comparisons between the 2 periods of data collection. Both Passey et al. and Hosten also recorded the heights of shrubs rooted within these transects in their field notes, from which we calculated ranges and averages. The apparently oldest sagebrushes within the plots, which were clipped by Passey et al. for ANAPA calibration in the beginning years, 1958-1960, were severed at their stem bases and had their growth rings counted for age estimation (Ferguson 1964).

One of the kipukas studied by Passey et al., Morgan's Pasture, was converted to intensive agriculture shortly after they had taken their last data. Fortunately, only 1 stand (\#459, Table 1) was studied at that kipuka for the earlier 10year sequence. Thus, Hosten repeated the earlier sampling effort only at the Carey, Kettle Butte, and Little Crater Kipukas where 4, 2, and 6 stands occurred, respectively. Field notes of Passey et al. indicate that stand \# 159 was actually located at Winter Kipuka, about $1.6 \mathrm{~km}$ SE of Little Crater Kipuka. However, we included stand \# 159 with the Little Crater stands in any kipuka-wide calculations. Hosten resampled these 12 locations each July from 1991 to 1993 , except for \#959, which was sampled only in 1991 because he was uncertain that it was indeed the same location Passey et al. used.

In addition to the evidence of soil pits, Hosten used aerial photos to delineate ecological site polygons (Creque et al. 1999) with internally similar elevation, slope, and exposure. The boundaries of stands chosen by Passey 
et al. were not recorded, but the numerous oblique, on-the-ground, eye-level photos they took helped Hosten determine where they had likely carried on their sampling efforts. Hosten also took 35-mm color slides of some of the same views Passey et al. had recorded and did a sign test comparison of stature, density (numbers per unit area), and foliage density of shrubs (similar to Noble 1977). The stature, density, and foliage density of shrubs were visually compared by projecting $35-\mathrm{mm}$ slides from the 2 sampling periods adjacent to each other. Two to 3 sets of photos (usually different perspectives) were examined at all stands except \#758 where earlier photos were not repeatable. Change was considered valid only if it was easily observed in more than 1 photo set.

Our examination of relationships of ANAPA to climate was done at several scales of spatial resolution. The first comparison was by kipuka. Passey et al. (1982: table 7) did collect cumulative precipitation in storage gauges on site from 1961 to 1969, with 2 readings made for each of the first 8 years over winter $(7$ October-31 March) and spring (1 April-30 June). Summer precipitation was not recorded. They found mainly weakly positive and even some negative coefficients of correlation when the 10year mean ANAPA was regressed with various durations of precipitation (Passey et al. 1982: table 6). Hosten (1995) did not report precipitation data at the kipukas.

To make comparisons of precipitation over nearly 50 years of interest, we used monthly precipitation and temperature data from nearby official long-term National Weather Service locations. We selected the closest available stations down the prevailing wind pattern (Daly et al. 1994) and at similar elevations to each kipuka (Table 1) in order to estimate cumulative annual crop-year (previous September-current June) precipitation (CYP). We calculated the mean and median CYP values for all 3 stations selected, both separately and collectively for each year. This procedure was justified because climatic similarities exist across the portion of the central Snake River Plains where the re-examined kipukas occur (Daly et al. 1994).

CYP is the single most robust climatic correlate to ANAPA yet found in this vegetation type (Sneva and Hyder 1962, Sneva and Brit- ton 1983, Sneva 1989). Median CYP and ANAPA values rather than means were used wherever possible, because mean values typically show a skewness to the right in frequency distributions of CYP for semiarid regions (Wilhite and Glantz 1985). Furthermore, the median is less influenced by a single extreme than is the mean (Daubenmire 1956).

As a potentially more sophisticated approach to characterizing between-drought and nondrought years, we tested relationships of ANAPA to the Palmer Drought Severity Index (PDSI; Alley 1984). PDSI data for Idaho Division 9, Upper Snake River Plain, were purchased from the National Oceanic and Atmospheric Administration (available from: http:// www.drought.noaa.gov). Years with a PDSI lower than -1.5 were considered a drought (Jensen 2003). We considered a "wet" year to have a PSDI $>1.5$. Years with values in between were considered "medial." We also calculated the ratio of ANAPA to CYP, an index also known as rainfall use efficiency (RUE), following Le Houerou et al. (1988).

Because changes in seasonal concentrations of precipitation can lead to changes in the various components of vegetation in semiarid regions (Curtin and Brown 2001), we also examined the data for that possibility. Winter was defined as January-March, spring as AprilJune, summer as July-September, and fall as October-December. We also tested for temporal autocorrelation in CYP between years (JMP 5.1 software). This was done with 1- to 6-year time lags.

Because an examination of mean ANAPAs for a kipuka combines data from 1 to 6 stands with different slopes, exposures, and soil profiles on different ecological sites (Creque et al. 1999), we also looked at some of the temporal patterns of vegetation responses at each of these stands separately, especially those not thoroughly discussed by Passey et al. or Hosten.

The length of the vegetational data sequences was too short for formal time series analyses. Because no "treatments" were imposed on a portion of the stands and because the response and driver variables are continuous rather than discrete (Cottingham et al. 2005), we used both simple linear regressions of ANAPA to CYP or species richness seperately, and multiple regressions of ANAPA to CYP and species richness together. Summaries and 


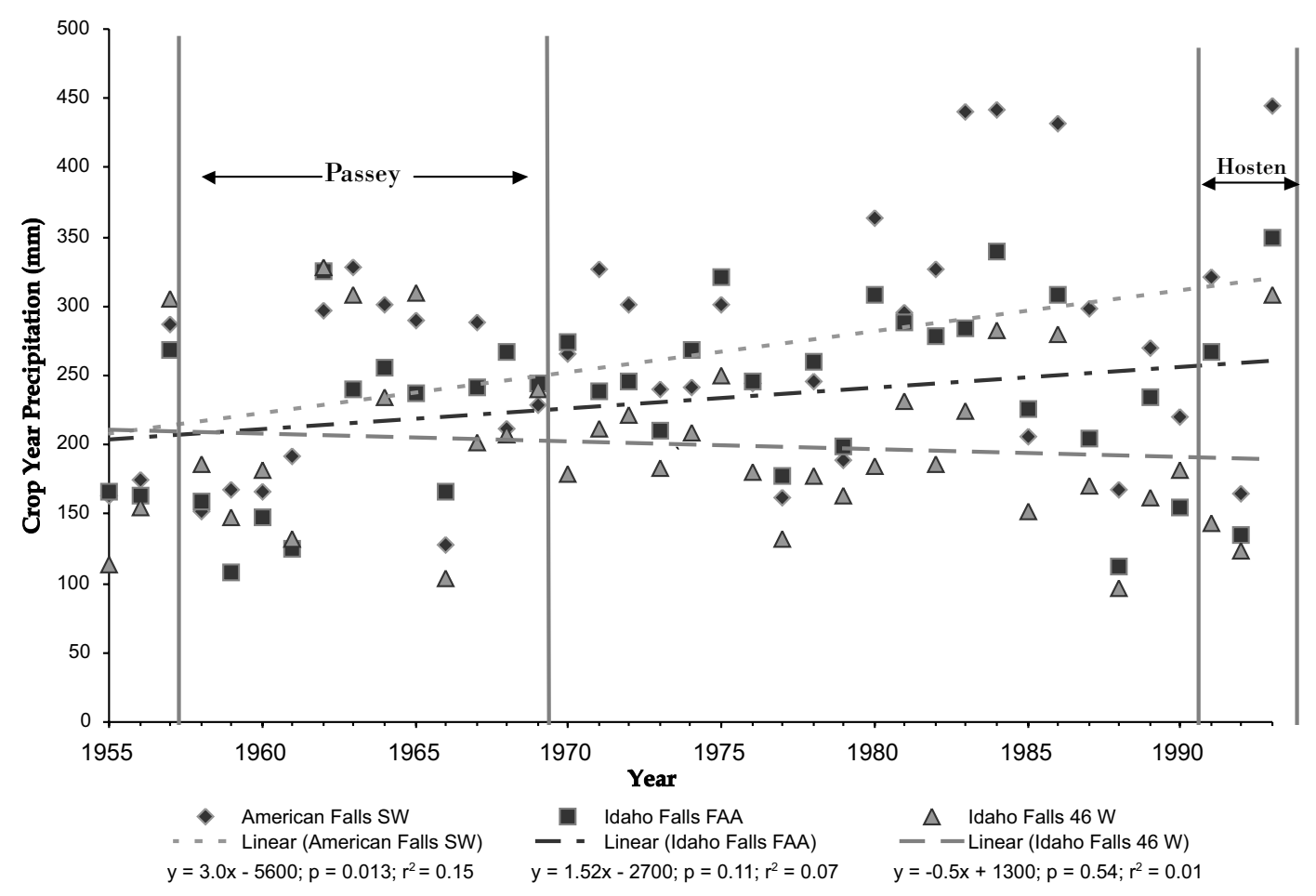

Fig. 1. Annual crop-year (1 September-30 June) precipitation (mm) from 1955 to 1995 at the 3 National Weather Service stations in southern Idaho closest to the study sites. "American Falls SW" is American Falls, located at $1320 \mathrm{~m}$ elevation, about $32 \mathrm{~km} \mathrm{SW}$ of Little Crater. "Idaho Falls FAA" is Idaho Falls, located at $1450 \mathrm{~m}$ elevation, about $31 \mathrm{~km}$ S of Kettle Butte and $40 \mathrm{~km}$ SE of Morgan Pasture. "Idaho Falls 46W" is actually Idaho National Engineering and Environmental Laboratory_Central Facilities Area, located at $1500 \mathrm{~m}$ elevation and about $64 \mathrm{~km}$ SE of Carey Kipuka.

scattergrams of all vegetational and climatic data we used will be provided to interested readers wanting to test alternative analyses. All relevant data, maps, and photographs will be archived under the senior author's name in the Special Collections Division of the Utah State University Library.

\section{RESUlTS}

\section{Precipitation}

Instrumental climatic data collection and analysis are fraught with numerous problems (Chapman and Harris 2004). Nevertheless, we needed climatic context in this vegetationfocused study. Since precipitation is widely acknowledged as the primary driving variable for plant production in the study area (Caldwell 1985), we began by examining temporal trends in precipitation during and between the 2 study periods (Fig. 1). The linear regression trend line over the 45 -year period of record was flat for Idaho Falls 46W (located at the Central Facilities Area of the Idaho National Engineering and Environmental Laboratory), but showed distinct, although statistically nonsignificant, upward trends for Idaho Falls FAA and American Falls, regardless of whether full calendar year (not shown) or crop year (CY) data (Fig. 1) were analyzed. We prefer CY to annual calendar year precipitation because such scaling shows less variation and makes more ecological sense. Precipitation occurring during the colder months of fall and winter, for the most part, infiltrates into the soil and becomes available for plant growth the following spring as air and soil temperatures warm. However, summer rainfall rarely infiltrates the soil to depths accessible to plant roots occurring in such ecosystems (West 1983).

Connecting the data points from each station for sequential years and overlaying lines for median values graphically illustrates the temporal variation in annual CYP totals and 


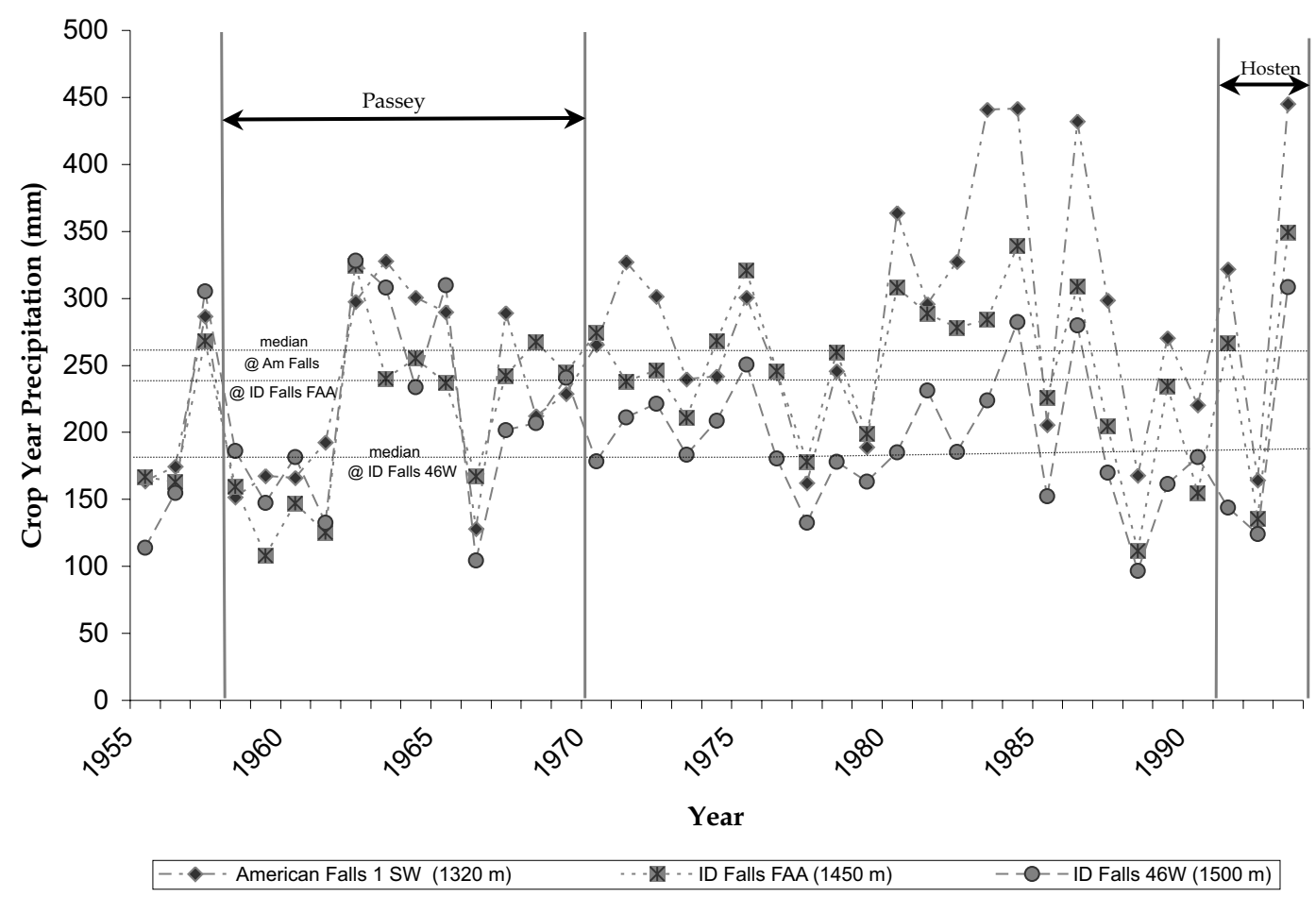

Fig. 2. Time courses (1955-1995) of medians of cumulative annual crop-year (previous September-current June) precipitation at the 3 National Weather Service stations closest to the study sites (see Fig. 1 for location descriptors).

shows that CYP did indeed vary considerably from year to year (Fig. 2). As an added measure of this variation, we also calculated coefficients of variation (COV) in CYP at the 3 climatic stations. The COVs for the CYPs ranged from $30 \%$ to $34 \%$, and averaged of $30 \%$ during the Passey et al. data collection period. Similar values observed during the Hosten sampling period ranged from $43 \%$ to $53 \%(\bar{x}=45 \%)$. A range of $23 \%$ to $29 \%(\bar{x}=24 \%)$ was found during the intervening period (1970-1990). However, visual examination of the range of differences (spreads) in annual CYP at the 3 stations (Fig. 2) indicated no marked difference between droughty years or years of medial precipitation.

The years during the intervening and Hosten periods appeared to be distinctly wetter than any of those occurring during the Passey et al. period. The results from using only CYP for defining drought, medial, and wet periods indicated that there were droughts in the mid1950 s through the early 1960s, and in the years 1966 and 1987. The CYP also indicated that 1957, 1961-1964, 1980-1983, and 1993 were wet years. Investigation of the possibility of temporal autocorrelations in annual CYP yielded no statistically significant results. The search for possible changes in the timing of precipitation within years showed no significant change in the ratio of winter (November-April) to growing season (May-September) precipitation over the 1955-1993 interval for any of the 3 stations (data not shown).

\section{Temperature}

Because higher temperatures reduce the effectiveness of precipitation for plant growth in these environments (Caldwell 1985), we next looked at trends in annual mean, maximum, and minimum temperatures over 40 years, 1955-1995, at the same stations where precipitation was recorded. There appeared to be little evidence of trend (Fig. 3). Converting these absolute data into deviations from normal (Fig. 4), called anomaly analysis (Steffen et al. 2004), showed that there were a few years at some stations (e.g., 1964 and 1985 at Idaho Falls FAA, and 1985 and 1993 at Idaho Falls $46 \mathrm{~W}$ ) when the lowest temperatures deviated 


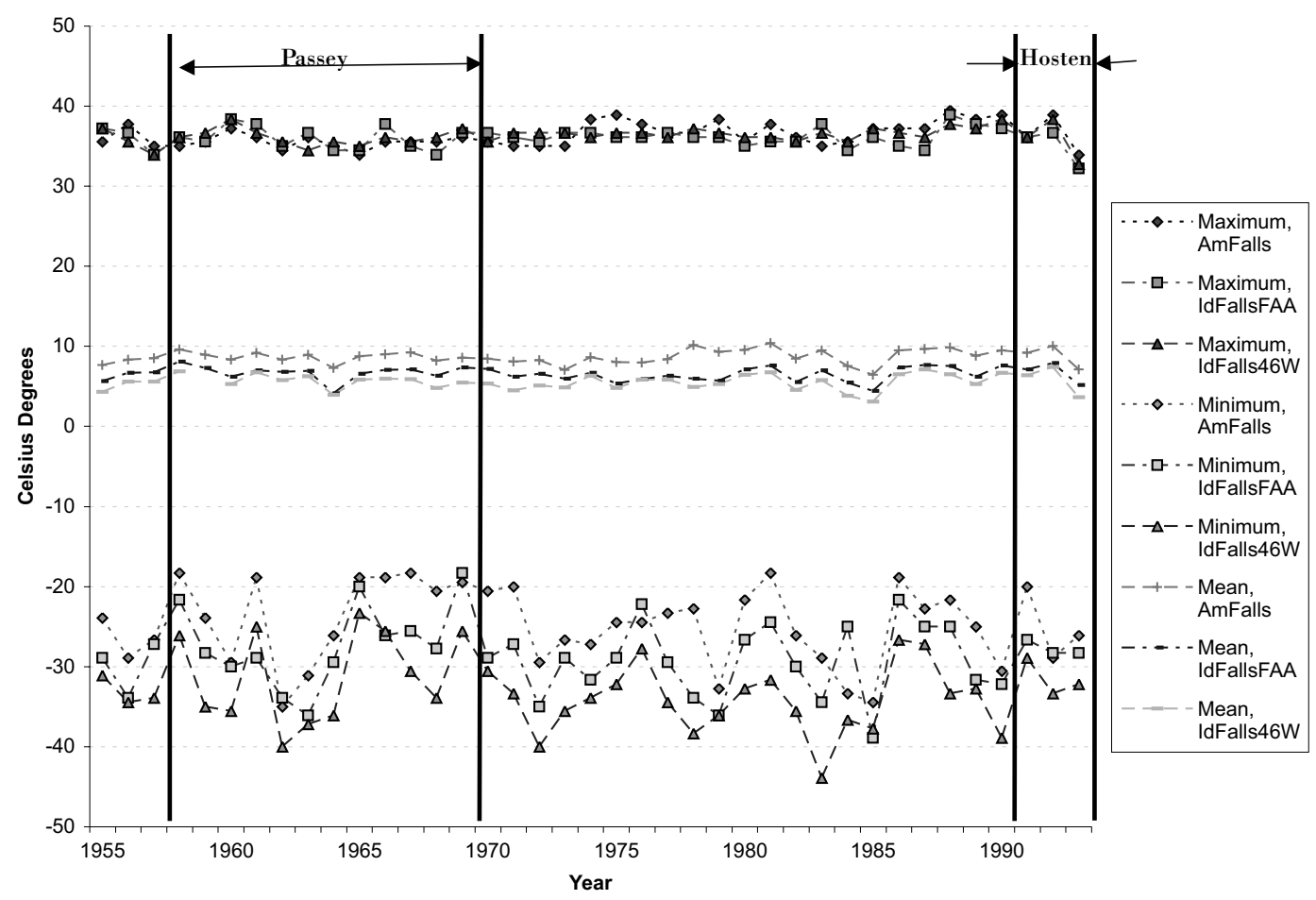

Fig. 3. Time courses (1955-1995) of annual mean, maximum, and minimum temperatures at the 3 National Weather Service stations closest to the study sites (see Fig. 1 for location descriptors).

over $2{ }^{\circ} \mathrm{C}$ below normal. Otherwise, we have no evidence that temperatures changed significantly at these stations over the period examined.

COVs in MATs across the 3 stations ranged from $7 \%$ to $15 \%$ with a mean of $11 \%$ during the Passey et al. sampling period; ranged from $17 \%$ to $33 \%$ with a mean of $22 \%$ during the Hosten sampling period; and ranged from $11 \%$ to $19 \%$ with a mean of $13 \%$ during the interim. MATs ranged from $2.3^{\circ}$ to $3.9^{\circ} \mathrm{C}$ around a median of $7.2^{\circ} \mathrm{C}$ for the 3 stations during the Passey et al. years. Related values ranged from $2.7^{\circ}$ to $3.1^{\circ} \mathrm{C}$ around a median of $7.5^{\circ} \mathrm{C}$ for the Hosten years, and $3.2^{\circ}$ to $4.0^{\circ} \mathrm{C}$ around a median of $6.8^{\circ} \mathrm{C}$ during the intervening period (1968-1992).

An analysis of spreads between the comparable MAT values at the 3 climatic stations revealed no temporal trends (data and analysis not illustrated). A test for temporal autocorrelation of MATs showed no significant relationships among years at any of the 3 stations during the study period. Thus, we were forced to conclude that, while temperatures fluctuate considerably from year to year, no detectable trend occurred in MATs, temperature extremes, or their COVs during the entire study period.

\section{Palmer Drought Severity Index (PDSI)}

Because the PDSI combines both precipitation and temperature, and their interactions, we logically viewed the values of this index (Fig. 5) as more closely linked to ANAPA than either precipitation or temperature considered independently. According to the Jensen (2003) threshold, the only drought years were in the 1961, 1977, 1988, and 1992 CYs. However, by a more liberal definition, a prolonged drought occurred from 1951 to 1961 (Fig. 5). Wetterthan-average conditions generally prevailed from 1962 to 1965 and again from 1969 to 1976 and in 1993.

Annual Net Aboveground Phytomass Accumulations (ANAPA)

TOTAL COMMUNiTy ANAPA IN RELATION TO CLIMATE.-Medians, means, standard errors of 


\section{Mean Annual Temperature Deviation from "Normal"}

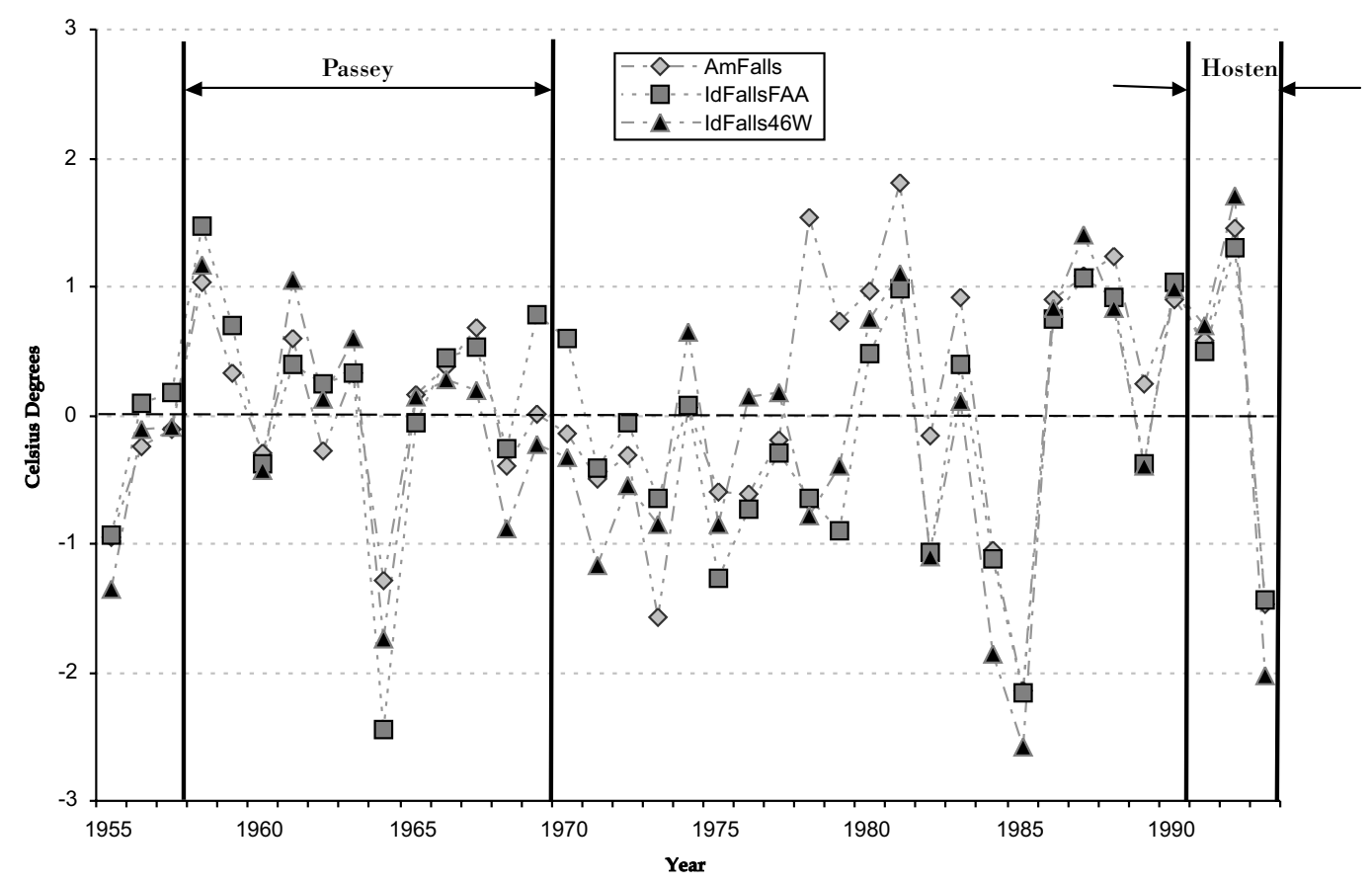

Fig. 4. Time courses (1955-1995) of mean annual temperature anomalies observed at the 3 National Weather Service stations closest to the study sites (see Fig. 1 for location descriptors).

means $\left(s_{\bar{x}}\right)$, and their associated COVs in total community ANAPA for the Passey et al. and Hosten sampling periods are shown in Table 1. Grand mean ANAPA values were over 200 $\mathrm{kg} \cdot \mathrm{ha}^{-1}$ greater during the Hosten period than the Passey et al. period (Table 1, bottom line). There was a statistically significant $(P=$ $0.007)$ upward trend in the fit of mean overall (all stands) ANAPA by year $\left(r^{2}=0.06\right)$ sequentially constrained (data not shown), but this may be driven by the lack of ANAPA data for the intervening years and the exceedingly wet conditions encountered in 1993.

COVs for the 10-year runs of ANAPA data showed a mean of $23 \%$ for the earlier Passey et al. period and $47 \%$ for the later Hosten period of 3 consecutive years. There was a slight $\left(r^{2}=0.2\right)$, but statistically insignificant increase in both mean and median ANAPAs (Table 1, down the columns) as the xeric-tomesic taxonomic soil moisture ranking of stands (in Passey et al.) increased.
Total community ANAPA data from all 4 kipukas examined by Passey et al. and the 3 kipukas reexamined by Hosten were regressed to a mean annual value for CYP at all 3 climatic stations. This temporally unconstrained analysis yielded an $r^{2}$ of 0.36 , significant at $P$ $<0.001$. Temporal contingency analysis showed no significant autocorrelations for current year's ANAPA up to 6 previous years. When regressions were restricted to total community ANAPAs at each kipuka each year (Fig. 6), the $r^{2}$ values and significance levels decreased, ranked in order of either the mean or median ANAPA values (Carey $>$ Little Crater $>$ Morgan $>$ Kettle). The time course of mean ANAPA (all stands; Fig. 7, topmost line) shows that, out of all ANAPAs observed each year, the $1993 \mathrm{CY}$ was an outlier.

Mean rainfall use efficiencies (RUEs) for the entire plant community ranged between 1.7 and 6.3 , but averaged 3.8 for the earlier, longer run of data and 4.1 for the later 3-year 


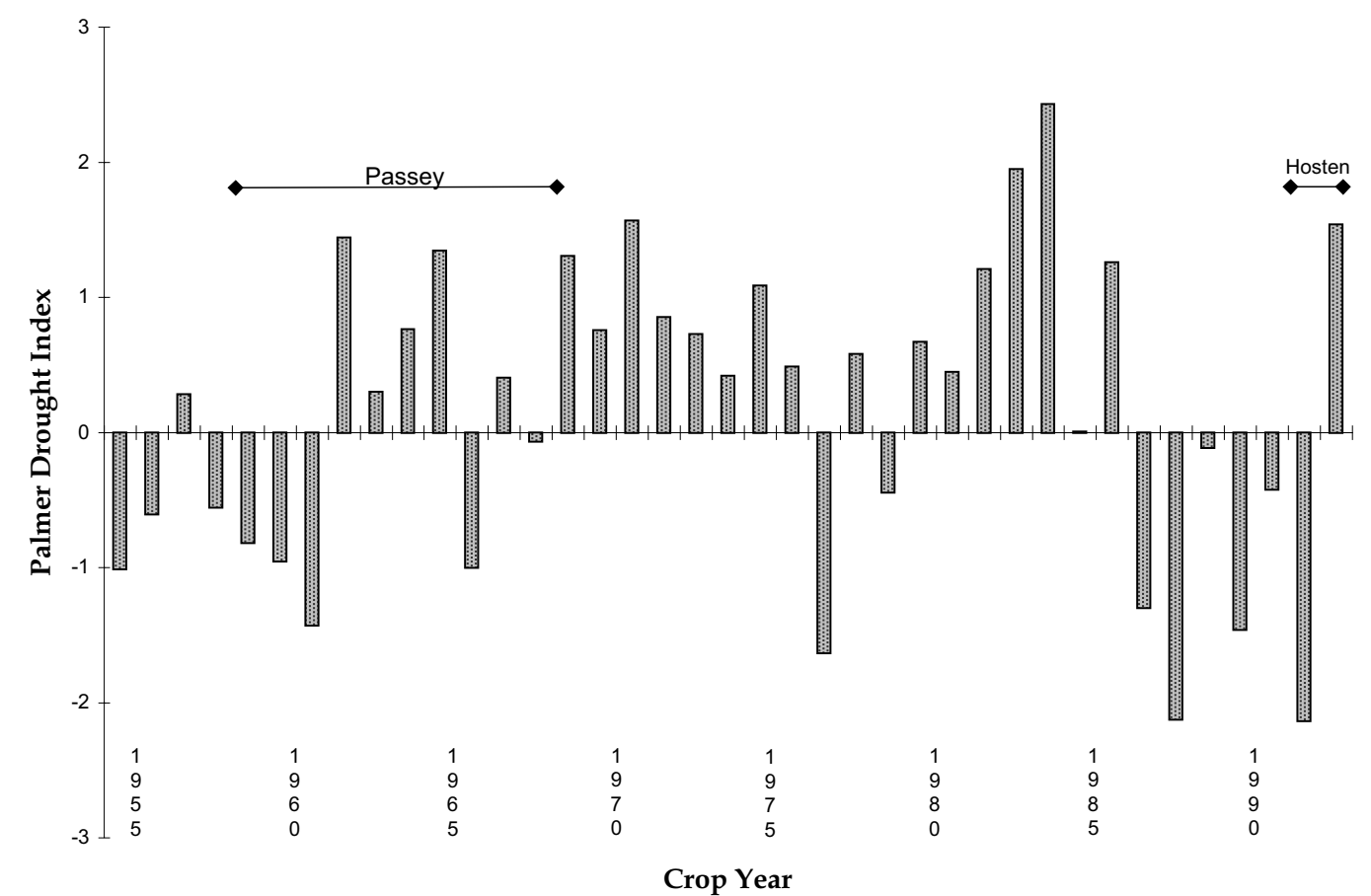

Fig. 5. Time courses (1955-1995) for the Palmer Drought Index in the eastern Snake River Plains region. Data were obtained from the Western Climate Data Center and analyzed by methods recommended by Alley (1984).

period in the early 1990s (Table 1). Slightly more of the possible comparisons (6 of 11) had lower RUE values in the 1990s than in the earlier period (Table 1). There was less numerical difference when medians were considered instead (Table 1).

Passey et al. previously and thoroughly analyzed the temporal patterns of ANAPA stand by stand, noting the lack of synchrony in maximal and minimal total ANAPA between stands on the same or different kipukas. We therefore saw little justification in reiterating their results or discussion of stand-by-stand differences. Passey et al. also contains many observations of how different species fluctuated in their responses to climate, especially in relation to soil distinctions.

Total Community ANAPA in Relation to Species Richness.-Using the data of Passey et al. (1982), Harper and Climer (1985) related the mean total community ANAPA over 10year runs to the mean species richness by stand over the same time period and found a strong positive relationship of ANAPA to increasing species richness. That approach, however, confounds the probable influences of year-to-year favorability due to climate, with long term site favorability also involving topography, soils, and geologic influences (Creque et al. 1999). To disentangle these influences, we used a variety of multivariate approaches (JMP 5.1 software from SAS). A MANOVA fit for ANAPA indicated a partial correlation of 0.58 for species richness and 0.57 for CYP. For the Passey et al. data, the partial correlation was 0.47 for richness and 0.48 for CYP, whereas for the Hosten data, it was 0.76 for richness and 0.68 for CYP. A multiple regression model for the complete data set with ANAPA as the dependent variable, adding species richness and CYP to construct model effects, accounted for $50 \%$ of the ANAPA variation, with a root mean square error of 240 . Both species richness and CYP were significant at $P<0.0001$, with the following overall prediction equation from parameter estimates: ANAPA $=-340+50$ richness +2 CYP. The $t$ ratio for richness was 7.8 , and for CYP was 7.4 , and the $F$-ratios were 60 and 55 , respectively. We interpreted these results to mean that increasing species richness had a slightly greater influence on increasing ANAPA than 


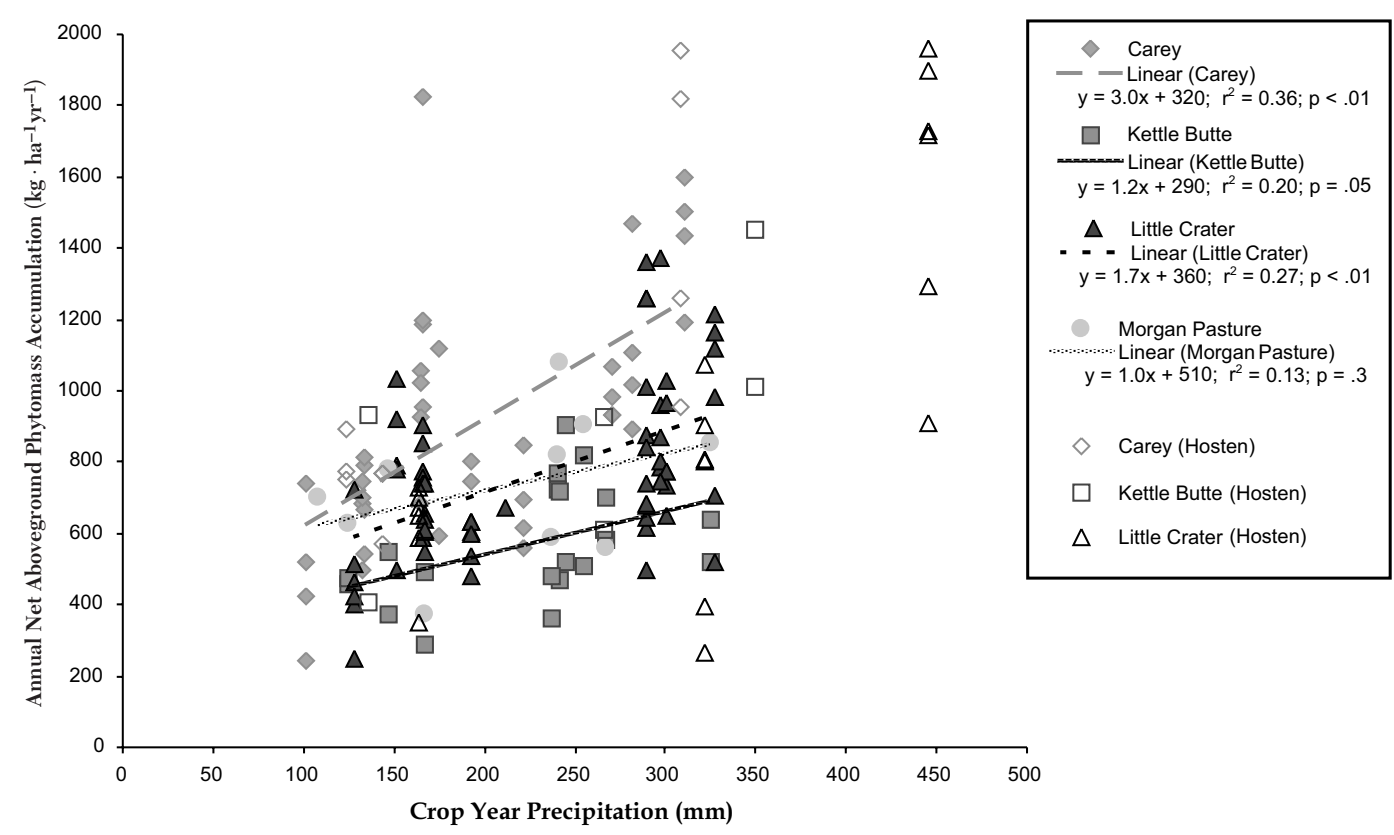

Fig. 6. Scattergram of ANAPA data points along with linear regressions and correlation analyses of ANAPA versus crop-year precipitation at the 4 kipukas. Values observed between 1958 and 1967 are represented by solid symbols. Values observed from 1991 to 1993 are represented by open symbols and are not included in the regression analyses. Morgan Pasture was not available during the later period.

increasing precipitation; however, both were strong, positive influences on total ANAPA in these circumstances.

ANAPA BY Growth Form Groups.Because the above comparisons were only modestly conclusive, we reordered the Passey et al. and Hosten ANAPA data by growth forms. This allowed us to show how the 4 main groups contributed to ANAPA each year. Figure 7 shows these temporal patterns in mean ANAPA (all stands aggregated) on an absolute basis. Figure 8 relativizes these patterns. Both analyses showed a marked increase in the abundance of shrubs by the latter study period. Whereas shrubs contributed relatively less to mean total ANAPA than either perennial grasses and forbs from 1958 through 1966, shrub contributions moved ahead of forbs in 1966 and ahead of grasses in 1991. Annuals, including Bromus tectorum, were minor contributors to mean total ANAPA throughout the 2 study periods.

To see if these trends were reliable, we also correlated the absolute contributions to ANAPAs by all woody plants in each stand by year in sequence. The slope of woody ANAPA had a significantly $(P<0.001)$ positive trend through time (adj. $\left.r^{2}=0.04\right)$. However, the apparently compensating decrease in grasses, although also significant $(P<0.005)$, had a shallower slope $(-4)$ and lower $r^{2}(0.04)$ than the slope for shrubs $(+10)$. Even when 1993 data were removed as aberrant, these relationships remained statistically significant $(P<$ $0.01)$, although the $r^{2}$ values dropped to essentially 0 . The increase in overall ANAPA with time, which could most logically account for the apparent difference in slope among growth forms, was even more clouded by the anomalously high CYP of 1993. With all data years included, that relationship had an increase of slope to $7\left(r^{2}=0.06, P=0.007\right)$, but without 1993 the slope fell to $0.44(P=0.8)$. Examination of the scatter of residuals (not shown) indicated no problems in the underlying homogeneity of variances.

\section{Shrub Maturity States}

The overall proportions of shrubs (all species combined) in all stands by maturity class showed few differences at the start of the 2 study periods (Fig. 9). Mature and partly dead 


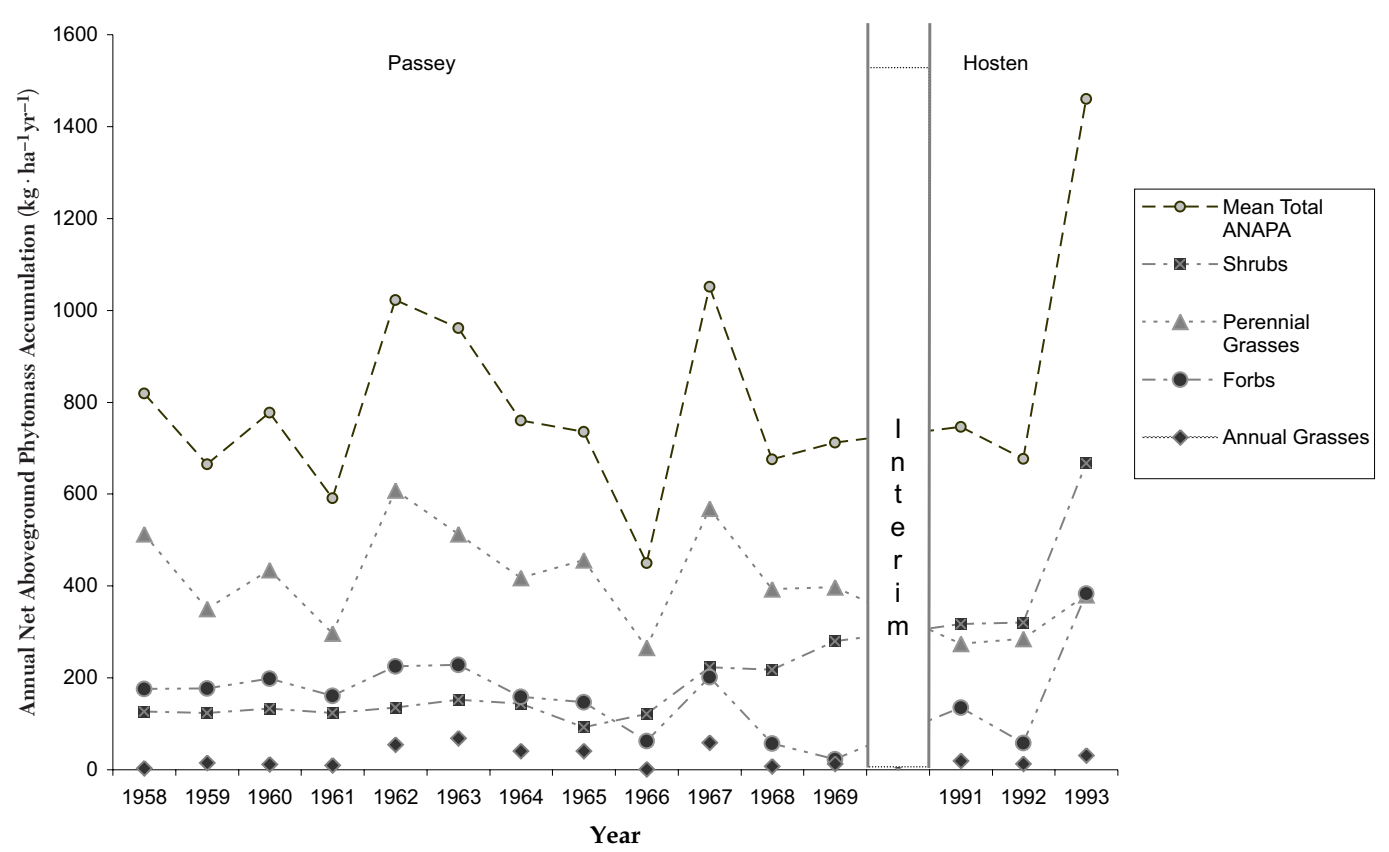

Fig. 7. Time courses of ANAPA (1958-1993) in total and by growth forms for all stands combined during the 2 study periods.

classes dominated at both times. The proportion of seedlings and immature Artemisia tridentata ssp. wyomingensis had increased in both stands at Kettle Butte, whereas the immature, mature, and partly dead classes increased in 3 of the 4 Carey stands (Table 2). Mature and partly dead A. tripartita classes increased at stand \#1758. Both A. tridentata ssp. wyomingensis and Chrysothamnus viscidiflorus increased at stand \#859, which had previously been devoid of shrubs (Table 2).

Average height and ranges in height of the dominant shrubs at each stand during the 2 examination periods are shown in Table 2 . Shrub height had increased at stands \#658, \#1258, and \#159 by the time Hosten reexamined them.

The maximum age of sagebrushes sampled by Passey et al. was about 120 years (Table 2 ). The shrubs of greatest ages were Artemisia tridentata ssp. wyomingensis and tended to be found on the most xeric sites (Table 1). Maximum shrub ages appeared to decline on the more mesic sites (Table 1).

From analysis of the paired photo sets, we found that shrub stature clearly increased on 3 stands (\#1258, \#1558, \#660; Table 2). Only 1 stand (\#859) showed an increase in the density of shrubs. Density of shrubs increased as site favorability increased (Table 2, left to right across). Foliage density increased on 5 stands (\#358, \#1558, \#859, \#959, \#660) by 1992.

\section{Discussion \\ Precipitation}

The previously noted vacillation of annual CYP between desert-like and grassland-like values for sagebrush steppe, in general (West 1983, 2000), and in particular (Blaisdell 1958), was indeed observed in the records at the representative climatic stations we examined. Figures 1 and 2 show up to almost 5 -fold differences in CYP at the same station during different, sometimes adjacent years. The generally high COVs in annual CYP also indicate that these examples occur in a highly temperate climate (Bailey 1964). There were no indications that the range of difference in annual CYP changed between drought, medial, and wet years at the 3 stations. This gives us more confidence in extrapolating CYP from stations (usually located in or near irrigated agricultural locales) to surrounding wildlands at similar elevations upwind of the prevailing air flow (Daly et al. 1994). 


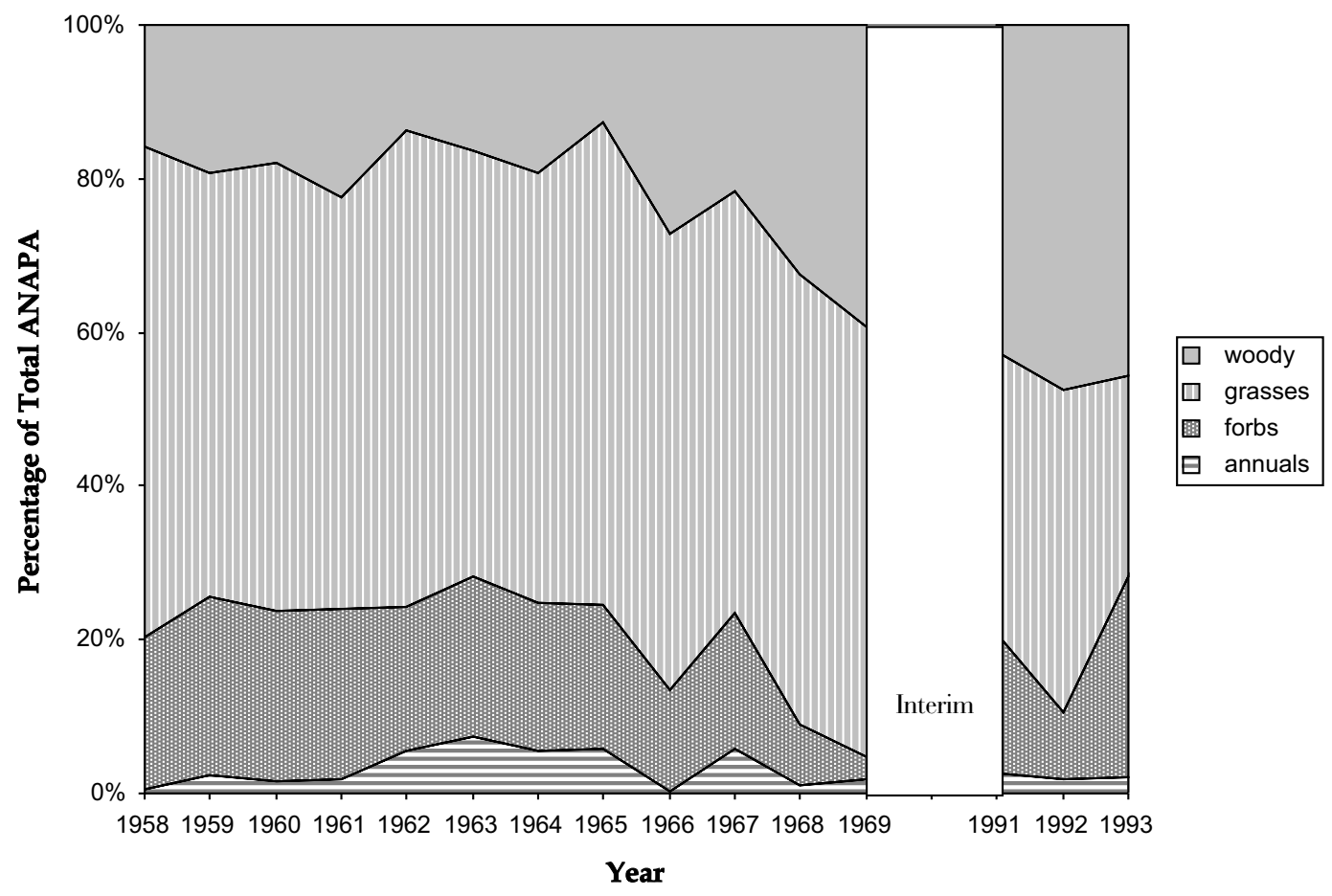

Fig. 8. Percentage of total ANAPA contributed by 4 plant growth forms to all stands combined during the 2 study periods.

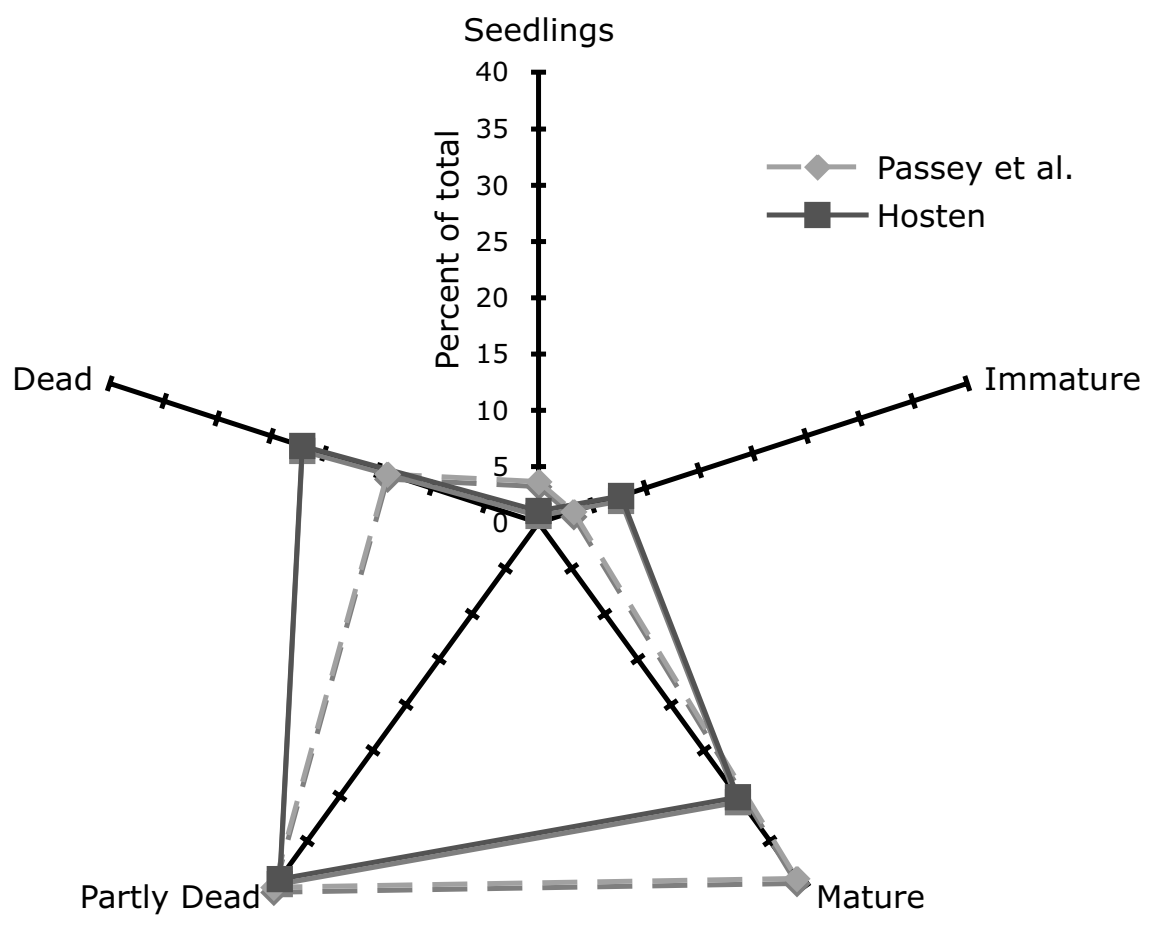

Fig. 9. Percentages by maturity class of all shrubs, all species, and all stands during the 2 study periods. 


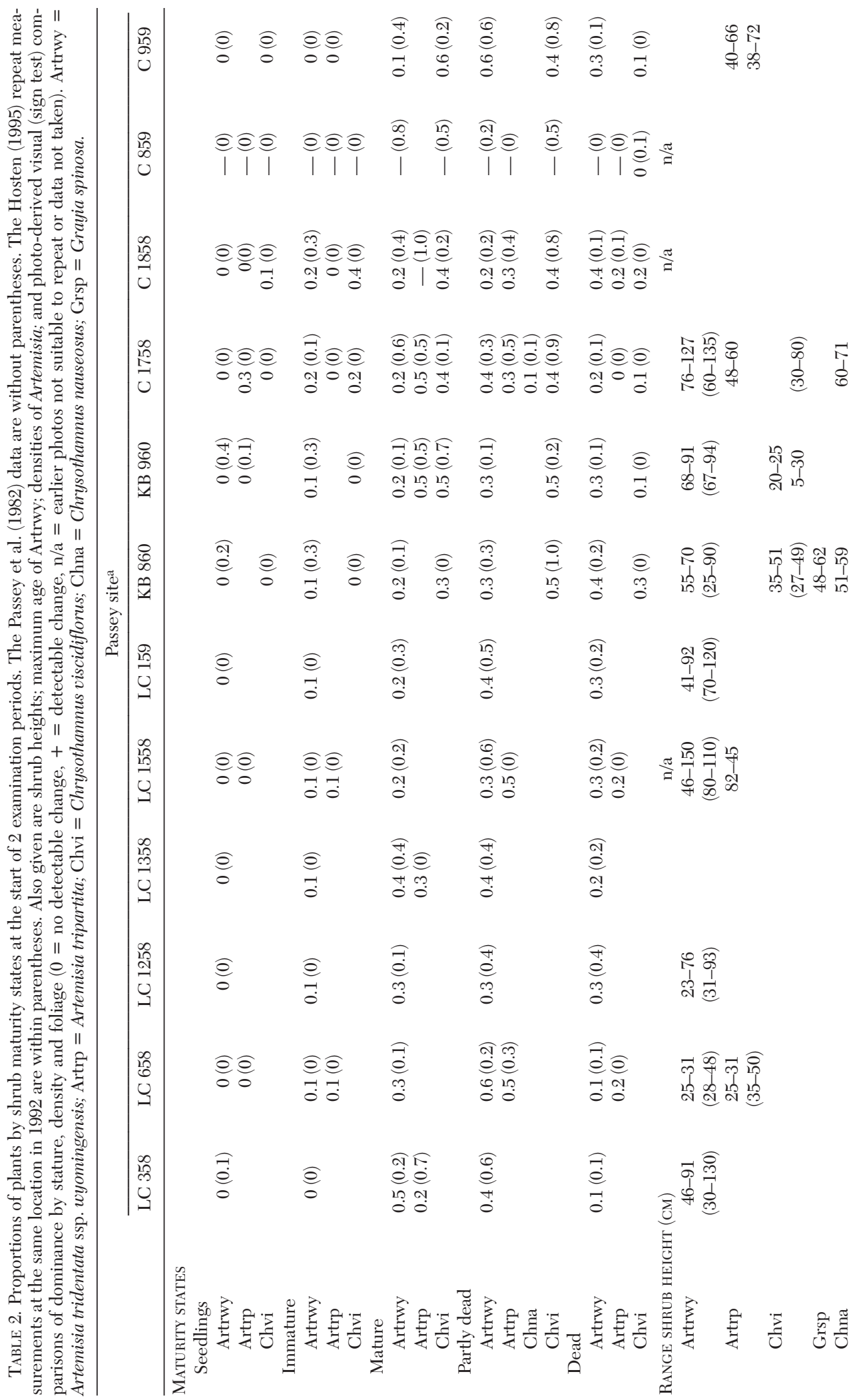




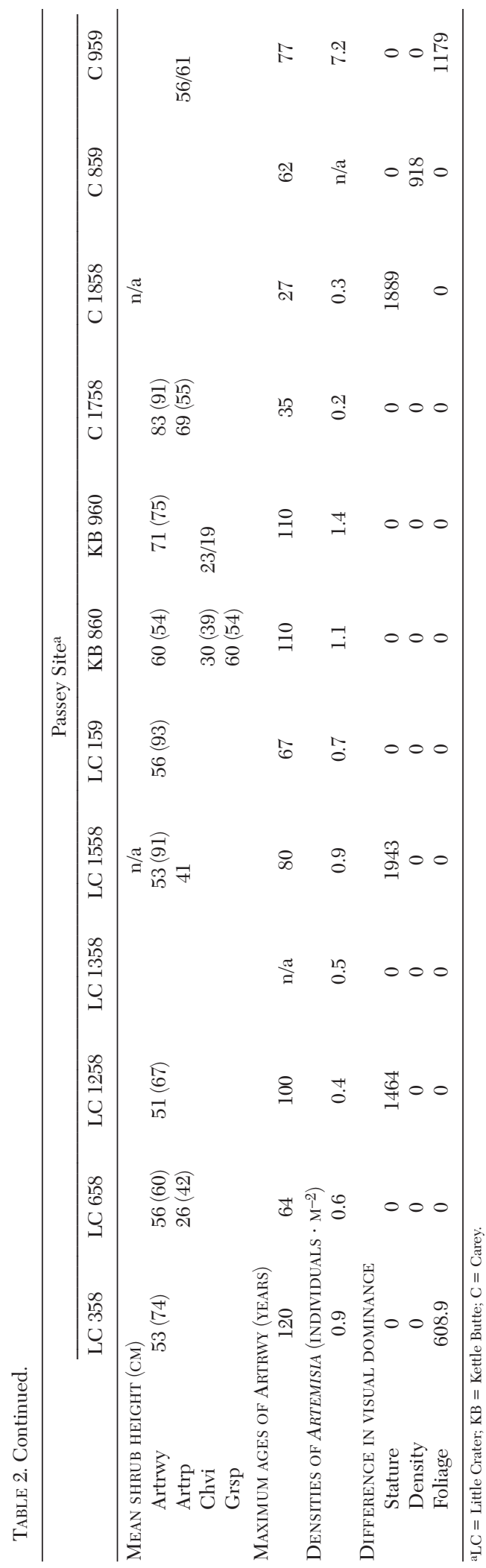

Droughts, medial periods, and wet periods can be defined a number of ways. Our definitions using CYP totals in a graphical mode seemed to visually indicate that there was seldom a single droughty, medial, or wet year; however, efforts to confirm this with temporal autocorrelation analyses failed.

Although such phenomena were unknown to Passey et al., we now realize that EN -SO and La Niña phenomena (Holmgren et al. 2001, Loik et al. 2004) have marked effects on vegetation in semiarid regions. Indeed, the study was begun shortly after the very dry La Niña years of the early 1950s, followed with a short EN-SO transitioning to La Niña events of the 1970s and 1980s. The extreme wetness around the 1983-1985 EÑ-SO was followed by a pronounced La Niña in 1988. Hosten just happened to have collected data during the longest EN-SO event of the twentieth century (Trenberth and Hoar 1996). The 2 study periods plus the intervening period also happened to straddle an upswing in the longer Pacific Decadal Oscillation (Gedalof et al. 2002). How much that burst of plant growth was reversed during the prolonged drought of the late 1990s and early years of the twenty-first century remains to be discovered by further studies.

\section{Temperature}

Contrary to the global increase in temperature over the past century, shown particularly through anomaly analysis (Steffen et al. 2004), we found no overall temporal trends in means, maximums, or minimums for our temperatures during the 45-year interval, by either direct or anomaly analysis. The length of record available to us was, however, shorter than that used by Steffen et al. (2004) and involved only 3 climate stations. We also found no overall trends in COVs for these features. These results suggest even greater confidence in extrapolating temperatures from the near-civilization stations than for CYP. This is because temperatures more easily equilibrate spatially, whereas precipitation, particularly from nonwinter convectional storm systems, follows irregular pathways. The trajectories of the more important winter frontal systems are more predictable (Daly et al. 1994). We were concerned, however, that MATs during the midst of the Passey et al. study period and at the end of the Hosten period were both coincidently lower 
than the long-term means. This could have made the precipitation more effective than it was during the remainder of the 45-year sequence.

\section{Palmer Drought Severity Index (PDSI)}

A generally droughty period from 1955 to 1961 (Fig. 5) coincided with the La Niña conditions occurring during those years, whereas the wetter-than-average conditions prevailing from 1962 to 1965,1969 to 1976 , and in 1993 correspond to EN-SOs (Bonan 2002). Thus, by coincidence, both Passey et al. and Hosten were studying this vegetation during relatively wetter periods following droughts.

\section{Other Atmospheric Impacts}

Severe wind and hail storms have been known to defoliate trees and shrubs, at least temporarily. Sagebrush is also subject to foliage mortality when warm periods occur while the ground is frozen and snow cover is less than usual (Hanson et al. 1982). Infrequent visits to such remote sites, particularly during fall and winter, could result in such impacts being missed by researchers. We suggest that future researchers plan to detect these potential influences using sensor web pods (Palmer et al. 2005).

While the increase in atmospheric $\mathrm{CO}_{2}$ is another possible contributer to increasing water-use efficiency and thus shrub dominance, we agree with Archer et al. (1995) that it is unlikely to play a role as great as other influences we emphasize in the following discussion. Several teams are attempting to measure the possible effects of increased $\mathrm{CO}_{2}$ on sagebrush and companion species under laboratory (Lucash et al. 2005) and field (Gilmanov et al. 2003, 2004) conditions, although none of their sites are on relict areas.

\section{Annual Net Aboveground Phytomass Accumulation} (ANAPA)

The significant increase in total mean ANAPA between the sampling periods likely occurred because 2 out of 3 years of observation in the early 1990s were fortuitously wetter than the median, especially the extremely wet year of 1993. Future investigators should attempt to accumulate longer temporal sequences of data to determine if these trends are enduring. For instance, Anderson and Inouye (2001) found that cover of both shrubs and grasses peaked in the mid- to late-1970s. Prior to 1950 their vegetation had likely been heavily grazed, but by 1995 it had recovered to a species composition similar to the vegetation discussed here.

Most startling about our comparisons is that shrubs were contributing proportionally more to ANAPA than grasses at the locations reexamined during the Hosten period. Whether these are compensating and permanent changes cannot be definitively answered by data currently available. We caution future investigators, however, not to view the situation necessarily as a zero-sum game, because all growth forms could be increasing their production in an absolute sense, as seen in 1993 (Fig. 7). The situation during that year was sufficient to make the increase of ANAPA for the whole period become statistically significant $(P<$ 0.007).

The mean ANAPAs for the 2 study periods are at the low end of the range of ANAPA values for sagebrush steppe in general (West 1983). The values presented here are also generally lower than those recorded nearby, but in the Upper rather than the Central Snake River Plains (Blaisdell 1958, Pearson 1965, 1966, Rumsey 1971). Most of the plant productivity data contained in the Natural Resources Conservation Service (NRCS) site guides are from areas that have been formerly and/or are currently being grazed by livestock. How these differences are partitioned between ecological site potential and successional status is difficult to determine. The NRCS is currently revising its field office technical guides so as to obtain this information. A states and transitions model for each ecological site (ES) will be used, rather than the former linear, deterministic, 1-successional-endpoint model of plant succession. Until this information becomes available it will not be possible to place the particular stands involved into appropriate ecological sites or successional states within those ecological sites. The expected revised ES descriptions will include expected ANAPAs during average, wetter-, or drier-than-average years.

In general our COVs of ANAPAs were higher than those reported by West (1983) and by Blaisdell (1958), the only other study with a reasonably long temporal sequence of data 
that was conducted at a nearby location. The Blaisdell (1958) study area had, however, been grazed up until construction of the exclosures in 1932. Anderson and Inouye (2001) found that at least 45 years of protection from grazing was required for detectable recovery of herbaceous perennial understory cover of sagebrush steppe. We agree with Anderson and Inouye (2001) that a partial explanation for the higher-than-usual COVs in ANAPA is likely a greater patchiness and lessened homogeneity within either ungrazed or long-rested stands in protected landscapes. What is less clear is how disturbances are crucial to creating the more spatially and compositionally diverse vegetation. Anderson and Inouye (2001) contend that lengthy rest from grazing is sufficient to create and maintain diverse sagebrush steppe; however, they could not directly address the productivity issues with only cover data.

We speculate that lack of livestock grazing combined with a general lack of fire on the relicts studied has allowed development of vegetation that more fully utilizes its environmental resources. Robertson and Pearse (1945) called this the closed community concept. Under such situations where long-lived, evergreen perennials dominate, inertia is created such that adjustments in the rates of productivity in relation to CYP are not as high or predictable as where grazing and/or fire have thinned out the stand and reduced the amounts of standing dead phytomass and litter and led to domination of younger age classes.

The graphs of total ANAPA each year at each stand (not shown) and collectively at each kipuka (Fig. 6) indicated some positive relationships of ANAPA to CYP (the assumed dominant driving variable). The fits, however, were not overwhelmingly tight. The tight fits of ANAPA to CYP reported by Blaisdell (1958), Sneva and Hyder (1962), Sneva and Britton (1983), and Sneva (1989) were derived from either heavily grazed sagebrush steppe or its cultural derivatives (e.g., crested wheatgrass monocultures).

Several deficiencies of our study design may also have contributed to poor relationships between ANAPA and CYP. As Passey et al. point out, the soils may not freeze during years of early and heavy snowfall. This allows most of the snowmelt (occurring at the soilsnow pack interface) to infiltrate into the soil profile. Fall rain and/or early snowmelt lead to freezing of the surface soil over the winter. Consequently, much of the water following winter snowfall can sublimate, and early spring rains run off as sheet flow rather than infiltrating the soil.

Another possible issue in obtaining tighter regressions of total ANAPA versus CYP is the spatial remoteness of the data used for CYP (Table 1). Passey et al. (1982: table 6), however, didn't find any overall tighter relationship with 8-year runs of partial on-site CYP data. In fact, they found some negative relationships, which Anderson and Inouye (2001) considered "spurious." Storms, especially convectional ones, are notoriously patchy. An additional problem is that it isn't the precipitation that falls into a collection device that makes plants grow, but rather precipitation that results in soil moisture available for plant use over subsequent days to weeks that counts (Loik et al. 2004). For instance, Collins et al. (2004) found that, rather than total cumulative annual or CY precipitation, accounting for temporal proximity in even lesser amounts of precipitation following a major storm yielded better explanatory power for changes in plant cover within a semiarid region of the southwestern U.S. Future research at these kipukas should take advantage of sensor web pods and other remote methods of monitoring precipitation (including snow, hail, rain, dew, etc.), temperature, wind, sublimation from the snowpack, evapotranspiration, soil moisture, and ANPP.

An additional constraint of the present study was that Passey et al. and Hosten examined vegetation on a very small fraction of each stand through their subsampling protocol. Size and shape of quadrats strongly influence enumeration of phytomass in sagebrush steppe (Pechanec and Stewart 1941), because variance of ANAPA values per stand is dependent on the mix of shrub-centered and interspace fractions of the mosaic included in the sampling units. Having a mix of fixed and newly located plots each year, as both Passey et al. and Hosten had, also complicates interpretations (West and Hatton 1990). Carefully randomized fixed plots reduce the confounding effects (due to varying numbers and placements of quadrats) of changing the ratios of shrub-centered/interspace structure sampled within stands during different years. Future work should use fixed locations sampled at multiple scales to 
determine if patch dynamics $(\mathrm{Wu}$ and Loucks 1995) are indeed operative within these stands as Passey et al. qualitatively imply and as Anderson and Inouye (2001) inferred by similarity analyses.

The Passey et al. and Hosten data admittedly represented only the selected stands, not the entire kipuka and all its component stands. Sampled areas were usually on elevated topography near the centers of the kipukas. There are other kinds of ecological sites (Creque et al. 1999), at lower elevations and nearer the fringing lava flows, that are probably more productive and dynamic than the ones Passey et al. and Hosten studied. Such sites have deeper soils and more accumulated moisture, largely due to snow drifting or rain running off the adjacent lava. That situation could occasionally lead to poor soil aeration and insect/ pathogen attack-forces that can reduce sagebrush (West 2000, Welch 2005).

Synoptic methods of remotely detecting productivity across entire landscapes are now available (Reeves et al. 2001). These are censuses and thus escape the sampling error of a small set of quadrats scattered throughout selected stands. Although such approaches yield information only on dominant life forms (Washington-Allen et al. 2004), not specieslevel differences, it would be interesting to do retrospective studies of the kipukas, possible back to 1972 , and prospectively use synoptic methods with any new on-the-ground investigations.

A major issue with interpreting past studies or planning future studies of these kipukas is how representative and complete they are compared to other examples of sagebrush steppe. The potentially most important environmental feature generally missing from these kipukas is fire. The length of fire-return intervals in presettlement sagebrush steppe is much debated (Miller and Eddleman 2001, Griffin 2002, Welch 2005). Miller and Eddleman (2001) reported fire-return intervals of 50-100 years in sites dominated by Wyoming big sagebrush and somewhat shorter intervals where more mesic sagebrushes (e.g., A. tripartita) prevail. These values apply to normal topography. The kipukas are isolated with intervening lava flows, which provide no connecting fuel loads and reduce the chance that lightning- or human-caused fires will either start or spread. Kipuka area varies from 0.7 $\mathrm{km}^{2}$ (Carey) to $0.2 \mathrm{~km}^{2}$ (Kettle Butte) to 0.07 $\mathrm{km}^{2}$ (Little Crater). The larger size of Morgan Pasture $\left(9.1 \mathrm{~km}^{2}\right)$ made it worth building the road to develop the intensive agriculture now there. The only fires likely to start on the kipukas require a direct hit by lightning when fuels are dry.

Obvious evidence of fire was mentioned by Passey et al. within only 1 stand at the Carey Kipuka (\#859), where charcoal was abundant at the soil surface. Shrubs were so sparse that shrub densities were not recorded (sampled) at that location. Exactly when fire occurred on the Casey Kipuka could not be determined.

Responses of vegetation to lack of fire can be further examined with the data on shrub maturity states that we inherited. The preponderance of mature, partially dead, and dead shrubs (Fig. 9, Table 2) of considerable age (up to 120 years; Table 2) means these stands are older and more decrepit than most mainland sagebrush stands. The ages are perhaps not the maximum possible (Ferguson 1964). Passey et al. remarked that many of the older plants had partially decayed, split stem-bases upon which growth rings could not be accurately counted. Thus, some of the sampled plants could have been older. Recall also that about 40 years have elapsed since Passey et al. took these samples. The low numbers of seedlings and juvenile shrubs contrasts with the "inverse-J" distribution of size classes expected in a "climax" stand (Barbour et al. 1987).

Unrepresentative fire regime is thus 1 of several features that diminish the utility of kipukas as reference areas for monitoring and restoration. The lack of fire on most of these kipukas for perhaps 10 times as long as the usual fire-return interval may be 1 reason for the lower than expected ANAPAs observed there. Even the 1 stand (\#859) with fire evidence was burned no less than 70-80 years ago. A literature review by Peterson and Flowers (1984) concluded that plant productivity in sagebrush steppe usually peaks about 15 years following a burn and declines thereafter as shrubs come to dominate.

Absence of fire and absence of livestock grazing are probably the principal causes of the increased shrub-to-herb ratios observed at the end of the Hosten study period. The isolation of the Carey Kipuka $(4.5 \mathrm{~km}$ from the nearest road) places high demands on animals, including humans. The Kettle Butte Kipuka is 
only about $1.5 \mathrm{~km}$ from a major highway and has a belt of surrounding lava narrowing to $0.08 \mathrm{~km}$ at its north end. Cut juniper stumps (probably from logging during the 1930s) and elk droppings were noted there by the authors during recent visits. The Little Crater Kipuka is surrounded by less-rugged lava than other kipukas, and that lava is $<1.5 \mathrm{~km}$ across at its narrowest. Deer use is common there. Sheep could also have been maintained there by a diligent herder when snow occurred as a water source.

Although large vertebrate grazers have obviously been absent or rare at these kipukas, we should not forget other possible grazers. Welch (2005) recently summarized information on grazing and decomposition of big sagebrush. Accordingly, we will mention these grazers only by class and include only relevant citations that Welch (2005) overlooked. Indigenous vertebrates known to consume sagebrush include jackrabbits, cottontail rabbits, pygmy rabbits (Brachylagus idahoensis), voles, pronghorn (Antilocapra americana), deer, and elk (Cervus elaphus). Arthropods noticeably influencing sagebrush steppe include moths, crickets, grasshoppers, leafhoppers, ants, termites, and wasps. Passey and Hugie (1963) only mention obvious defoliation of sagebrush by larvae of the moth Aroga websteri on the Little Crater Kipuka during 1960 through 1961.

Another negative influence on Artemisia, noted elsewhere (Allen et al. 1987) but not observed by either Passey et al. or Hosten, is snow mold. The grassy fringes of kipukas near the bordering lava generally lack sagebrush and other shrubs. Additional snow drift accumulations and poor soil aeration at times of soil water saturation (Wallace and Nelson 1990) could keep sagebrush diminished at such locations. Unfortunately, no direct observations were made at these kipukas during the regionwide "shrub die-off" during the 1970s and 1980s (Wallace and Nelson 1980). Anderson and Inouye (2001) noted considerable reductions in shrub cover at their nearby sites in synchrony with these regional reductions. It is doubtful, however, that sagebrush could have reached such "superdominance" in productivity at the kipukas in the 1990s if a large reduction in shrubs had occurred then.

Moderate activity of grazers, decomposers, and pathogens is known to stimulate rates of primary production (Loesser et al. 2004), de- composition, and nutrient cycling (Chapin et al. 2002) in similar ecosystems. Others (Pechanec et al. 1937, Tueller and Tower 1979) have noted lower productivity within exclosures when large vertebrate grazers are excluded. This effect is partly the result of older plants dominating the stand. Older plants have less new growth than younger plants (Peterson and Flowers 1984). Passey et al. (1982:47) remarked, "It was repeatedly observed that growth, size and reproductive success of major plant species were lower in ungrazed, near-climax stands than in grazed stands on similar soils." Future work needs to better quantify these comparisons.

Presumably, nutrients such as nitrogen (West 1991) get sequestered in the long-lived browse and its standing dead phytomass. When animals do not consume or trample these materials into litter that decomposers can process, nutrient cycling slows and lower nutrients in soil become limiting to plant growth. This possible tightening of nutrient cycles is reflected in the controls for a recent nearby experiment employing irrigation on sagebrush steppe (Morris 2001). Singer (1995) and Sneva and Britton (1983) have given this as a possible reason they obtained stronger fits of forage production to CYP for grazed areas in similar environments. Frank and McNaughton (1993) noted $47 \%$ higher ANPP on plots grazed by large native ungulates compared to matched exclosures within sagebrush steppe in the northern rangeland of Yellowstone National Park. That difference was largely due to grasses. Singer and Renken (1995) noted significant reductions in the brush that wasn't protected from these ungulates in the same general area. Singer and Schoenecker (2003) noted accelerated nitrogen cycling at the same Yellowstone locations. Pearson (1965) also noted that higher ANAPA occurred on one of a pair of sites with continued grazing which had younger plants than the one on which grazing had been excluded. Experiments designed to test diminished nutrient cycling as a cause for the difference would probably not be allowed on relicts because of the ethical implications of introducing livestock grazing (or its proxy) to such rare, ungrazed areas. The recent intrusion of elk onto the Kettle Butte Kipuka may pose an opportunity to study a "natural" introduction of grazers.

The RUE values we observed were well within the expected range (LeHouerou et al. 
1988), although the average degree of efficiency apparently increased between the Passey et al. and Hosten study periods (Table 1, bottom line), albeit with a great amount of variation. Nevertheless, the trend is compatible with our other lines of logic. Thomas and Squires (1991) promoted RUEs as a way to monitor ecological status of rangeland vegetation. If long runs of on-site precipitation and other meteorological data, especially soil moisture (Loik et al. 2004), become available and are considered along with more synoptic measures of ANPP, perhaps RUEs can be more reliably employed.

We would have liked to address the equatability of species richness in relation to ANAPA, but we had reservations about whether Passey et al. completely accounted for all plant species. The only years of ANAPA data without this problem were collected by Hosten, but the 3year run was too short to adequately address these issues. Nevertheless, our observation of a strong correlation of ANAPA to increasing species richness should be of interest to researchers planning well-designed and wellexecuted studies of these relationships.

After the unusually high ANAPA that Hosten observed in 1993 (following a very wet winter), sagebrush failed to drop its ephemeral leaves (Miller and Shultz 1987) by the time of data collection, a situation observed only one other time. This may enhance the apparent "superdominance" of sagebrush observed at the end of Hosten's data collection. If data on total standing crops (including standing dead phytomass and litter) had been taken, sagebrush would have appeared as an even more striking "superdominant."

Future researchers need to identify and include the numerous microphytes (mosses, lichens, and algae; Neitlich et al. 2003) present at these relict sites. Neither Passey et al. nor Hosten deposited comprehensive sets of voucher specimens in herbaria, something future researchers should also do.

We had no doubts about the consistent identification of Bromus tectorum (cheatgrass), a major invader of sagebrush steppe (Billings 1994). Hosten remarked about the minor role this aggressive winter annual grass has had so far on these particular kipukas. Other kipukas, however, are already dominated by cheatgrass (Lovejoy 1980; N. Huntly, 10 March 2005, per- sonal communication). Explanations for these differences in susceptibility of kikupas to invasion and dominance shifts remain to be discovered.

Hosten had more reliable species-level data than Passey et al. and he did some analyses (e.g., ordinations and serial correlations) that we avoided extending to the Passey et al. data because these methods are sensitive to missing phytomass data. Hosten didn't aggregate the data into life forms like we opted to do. Thus, he missed the dramatic shift in shrub/ understory ratios. Our findings support Axiom \#8 in Welch and Criddle (2003), which states that sagebrush can competitively reduce understory production. The partially evergreen Artemisia species transpire year-round and draw down soil moisture more than other plants (Link et al. 1994). The longer-lived shrub tissues also sequester a large pool of nutrients (Murray 1975).

Passey et al. assumed that the kipukas had climax vegetation from the outset and described all their observed variations as fluctuations within a climax state. Hosten avoided the issue of climax status, addressing multiple states and transitions instead. Our finding of dramatic increases in the shrub-to-grass ratio led us to conclude that succession (directional change) was not yet complete in these systems. The "super dominance" recently achieved by sagebrush may be a function of lack of grazing by large vertebrates, and, especially, a prolonged fire-free interval compared to similar vegetation on less isolated terrain. Nevertheless, because of this reanalysis of others' data on sites without direct impacts of humans, we have learned more about some understudied phenomena and we better understand the dynamics of sagebrush steppe vegetation. Clements' (1934) admonition that observation of relicts should be more than casual still holds.

\section{Conclusions}

Reexamination of vegetational and climatic data from 3 relictual areas on the Snake River Plains of southern Idaho, studied in 2 periods about 30 years apart, revealed that the structure and productivity of this vegetation does indeed show considerable fluctuations. These fluctuations are largely explainable by variations in crop-year precipitation and an index of drought. If stability can be operationally 
defined as lack of observed change (level trend) in the averages of vegetational variables such as ANAPA and their components such as life forms, then stability was not demonstrated between 1958 and 1969 and between 1991 and 1993 for these examples of sagebrush steppe. Shrubs, particularly sagebrushes, made up a dramatically increased proportion of the annual net aboveground phytomass increment, while herbs decreased toward the last data collection period, 1991-1993. However, the apparent increase in total ANAPA between the Passey et al. and Hosten sampling periods may be largely due to the unusually wet year of 1993 .

Rather than climatic change, for which no significant long-term trends were found in either the instrumental records or the modeled patterns, it seems more likely that the near absence of vertebrate grazing and fire allowed the brush to progressively increase its dominance over herbs. Admittedly, the roles of invertebrates, decomposers, and pathogens are unknown at the study areas. Nevertheless, sagebrush had become a "superdominant" without livestock grazing, the cause usually invoked for this phenomenon (Anderson and Inouye 2001). Lower-than-expected levels of total plant production could have resulted as nutrients became sequestered in the long-lived shrub tissues. This, along with the mature soil development of the kipukas, which are on older landscapes than the nearby non-kipuka areas on the "mainland," appears to depreciate the value of such relicts as reference areas in monitoring the condition of managed areas within the region. This situation also limits use of these kipukas as living examples of restoration end points.

We encourage others to repeat and strengthen these studies at these areas to track further directional changes, either related to the above issues or due to expected climatic shifts. We have archived the original data and photographs for this purpose. We have also suggested how such studies can be better designed and executed so that future findings will be more definitive.

\section{ACKNOWLEDGMENTS}

We thank John Menke for suggesting this study. This work was achieved using Grant No. 90-38300-5098 from the Special Rangelands Research Program of the Cooperative
States Research Service of the U.S. Department of Agriculture to N.E. West. We heartily thank Steve Leonard for his careful stewardship of the Passey et al. (1982) data. In addition to the team members who collected the Passey et al. (1982) data, Paul Hosten, Mirzo Baig, Jill Schroeder, Jeff Creque, Ed Dickie, and Jason Dickie deserve special mention for their field work during the latter study period. This paper was approved by the director of the Utah Agricultural Experiment Station as Paper No. 4762. The Passey et al. (1982) data and photo files, as well as Hosten's (1995) more recent data and photos, have been placed in the Utah State University Library Special Collections (under the name of N.E. West) to facilitate future reexamination of vegetation change on these relicts.

\section{Literature Cited}

Allen, M.F., E.B. Allen, AND N.E. West. 1987. Influence of parasitic and mutualistic fungi on temperate semidesert shrubs. Bulletin of the Torrey Botanical Club 114:272-279.

Alley, W. 1984. The Palmer Drought Severity Index: limitations and assumptions. Journal of Climate and Applied Meteorology 23:1100-1109.

Anderson, J.E., AND R.S. InOuYe. 2001. Landscape-scale changes in plant species abundance and biodiversity of a sagebrush steppe over 45 years. Ecological Monographs 71:531-556.

Archer, S., AND A. Bowman. 2002. Understanding and managing rangeland plant communities. Pages 63-80 in A.C. Grice and K.C. Hodgkinson, editors, Global rangelands: progress and prospects. CAB International, Wallinford, U.K.

Archer, S., D.S. Schimel, and E.A. Holland. 1995. Mechanisms of shrubland expansion: land use, climate or $\mathrm{CO}_{2}$. Climatic Change 29:91-99.

BaILEY, H.P. 1964. Toward a unified concept of the temperate climate. Geographical Review 54:516-545.

Barbour, M.G., J.H. Burk, AND W.D. PitTs. 1987. Terrestrial plant ecology. 2nd edition. Benjamin Cummings Publishing Co., Menlo Park, CA.

BILLINGS, W.D. 1994. Ecological impacts of cheatgrass and resultant fire on ecosystems in the western Great Basin. Pages 22-30 in S.B. Monsen and S.G. Kitchen, compilers, Proceedings - ecology and management of annual rangelands. General Technical Report INT-GTR-313, USDA Forest Service, Intermountain Research Station, Ogden, UT.

BLAisDELL, J.P. 1958. Seasonal development and yield of native plants in the Upper Snake River Plains. U.S. Department of Agriculture Technical Bulletin 1190. $68 \mathrm{pp}$.

Bonan, G. 2002. Ecological climatology: concepts and applications. Cambridge University Press, Cambridge, U.K. 678 pp.

BonHam, C.D. 1989. Measurements for terrestrial vegetation. Wiley-Interscience, New York. 338 pp. 
Bunting, S.C., J.L. Kingery, M.A. Hemstrom, M.A. Schroeder, R.A. Gravenmier, and W.J. Hann. 2002. Altered rangeland ecosystems in the Interior Columbia Basin. General Technical Report PNWGTR-553, USDA Forest Service, Pacific Northwest Research Station.

[BLM] Bureau of Land Management. 2002. Management consideration for sagebrush (Artemisia) in the western United States. USDI Bureau of Land Management, Washington DC. 73 pp.

Caldwell, M. 1985. Cold desert. Pages 198-212 in B.F. Chabot and H.A. Mooney, editors, Physiological ecology of North American plant communities. Chapman and Hall, New York.

Chapin, F.S., III, P.A. Matson, and H.A. Mooney. 2002. Principles of terrestrial ecosystem ecology. Springer, New York. 436 pp.

Chapman, D.S., AND R.N. HARRIS. 2004. Surface warming in the Northern Hemisphere inferred from borehole temperatures. Pages 43-44 in Abstracts, Pacific Division, American Association for the Advancement of Science. Logan, UT.

Clements, F.E. 1934. The relict method in dynamic ecology. Journal of Ecology 22:39-68.

Collins, S.L., E.H. Muldavin, S.M. Munson, and D.I. MoORe. 2004. Community dynamics and stability in semi-arid grassland vegetation. Abstracts, 89th annual meeting, Ecological Society of America.

Cook, J.G., AND L.L. Irwin. 1992. Climate between the Great Plains and Great Basin. American Midland Naturalist 127:316-326.

Cottingham, K.L., J.T. Lennon, and B.L. Brown. 2005. Knowing when to draw the line: designing more informative ecological experiments. Frontiers of Ecology and Environment 3:145-152.

Creque, J.A., S.D. Bassett, And N.E. West. 1999. Viewpoint: delineating ecological sites. Journal of Range Management 52:546-549.

Curtin, C.G., And J.H. Brown. 2001. Climate and herbivory in structuring the vegetation of the Malpai Borderlands. Pages 84-94 in G.L. Webster and C.J. Bahre, editors, Changing plant life of LaFrontera: observations on vegetation in the United States / Mexico borderlands. University of New Mexico Press, Albuquerque, NM.

Daly, C., R.P. Neilson, and D.L. Phillips. 1994. A statistical-topographic model for mapping climatological precipitation over mountainous terrain. Journal of Applied Meteorology 33:140-158.

Daubenmire, R.F. 1956. Climate as a determinant of vegetation distribution in eastern Washington and northern Idaho. Ecological Monographs 26:131-154.

Ferguson, C.W. 1964. Annual rings in big sagebrush. Papers of the Laboratory of Tree-Ring Research No. 1. University of Arizona Press, Tucson. 95 pp.

Ferguson, S.A. 1997. A climate-change scenario for the Columbia River Basin. Pages 23-25 in T.M. Quigley, R.W. Haynes, and R.T. Graham, editors, Interior Columbia River Basin Ecosystem Management Project: scientific assessment. General Technical Report PNW-GTR-382, USDA Forest Service, Pacific Northwest Research Station, Portland, OR.

FORD, E.D. 2000. Scientific method for ecological research. Cambridge University Press, New York. 564 pp.

Frank, D.A., AND S.J. McNaughton. 1993. Evidence for the promotion of aboveground grassland production by native large herbivores in Yellowstone National Park. Oecologia 96:157-161.

Gedalof, Z., N. Mantua, and D.L. Peterson. 2002. A multi-century perspective of variability in the Pacific Decadal Oscillation: new insights from tree rings and coral. Geophysical Research Letters 29:22042207.

Gilmanov, T.G., D.A. Johnson, And N.Z. Saliendra. 2003. Growing season $\mathrm{CO}_{2}$ fluxes in sagebrush steppe ecosystem in Idaho: Bowen ratio / energy balance measurements and modeling. Basic and Applied Ecology 4:167-183.

Gilmanov, T.G., D.A. Johnson, N.Z. Saliendra, T.J. SveJCAR, R.F. ANGELL, and K.L. Clawson. 2004. Winter $\mathrm{CO}_{2}$ fluxes above sagebrush steppe ecosystems in Idaho and Oregon. Agricultural and Forest Meteorology 126:73-88.

Giorgi, F., C.S. Brodeur, and G.T. Bates. 1994. Regional climate change scenarios over the United States produced with a nested regional climate model. Journal of Climate 7:375-399.

Griffin, D. 2002. Prehistoric human impacts on fire regimes and vegetation in the northern Intermountain West. Pages 77-100 in T.R. Vale, editor, Fire, native peoples, and the natural landscape. Island Press, Washington, DC.

Hanson, C.L., C.W. Johnson, and J.W. Wight. 1982. Foliage mortality of mountain big sagebrush (Artemisia tridentata ssp. vaseyana) in southwestern Idaho during the winter of 1966-67. Journal of Range Management 35:142-145.

Harper, K.T., AND S.C. Climer. 1985. Factors effecting productivity and compositional stability of Artemisia steppes in Idaho and Utah, USA. Pages 592-594 in T. Okuba and M. Shiyomi, editors, Proceedings of the XVth International Grassland Congress, Kyoto, Japan.

HocketT, G.A. 2002. Livestock impacts on the herbaceous components of sage grouse habitat: a review. Intermountain Journal of Sciences 8:105-114.

Holmgren, M., M. Scheffer, E. Ezcurra, J.R. GutierREZ, AND G.M.J. MoHren. 2001. El-Niño effects on the dynamics of terrestrial ecosystems. Trends in Ecology and Evolution 16:89-94.

Hosten, P.E. 1995. Assessing the relative utility of models of vegetation dynamics for the management of sagebrush steppe rangelands. Doctoral dissertation, Utah State University, Logan. 194 pp.

Jensen, D.T. 2003. Monitoring drought in the West. Arid Land Research and Management 17:449-454.

Lauenroth, W.K., H.E. Epstein, J.M. Paruelo, I.C. Burke, M.R. Aguiar, And O.E. Sala. 2004. Potential effects of climate change on the temperate zones of North and South America. Revista Chilena de Historia Natural 77:439-453.

LeHouerou, H.N., R.L. Bingham, and W. Skerbek. 1988. Relationship between the variability of primary production and the variability of annual precipitation in world arid lands. Journal of Arid Environments 15: $1-18$.

Link, S.O., W.J. Waugh, J.L. Downs, M.E. Thiede, J.C. Chatters, and G.W. GeE. 1994. Effects of coppice dune topography and vegetation on soil water dynamics in a cold-desert ecosystem. Journal of Arid Environments 27:265-278.

Loeser, M.R., T.E. Crews, AND T.D. Sisk. 2004. Defoliation increased above-ground productivity in a semi- 
arid grassland. Journal of Range Management 57 : 442-447.

Loik, M.E., D.D. Breshears, W.K. Lauenroth, and J. BELNAP. 2004. A multi-scale perspective of water pulses in dryland ecosystems: climatology and ecohydrology of the western USA. Oecologia 141:269281

LoveJoy, S.H. 1980. Patterns in the distribution of plants and animals on lava flows and kipukas in southeastern Idaho. Master's thesis, Idaho State University, Pocatello.

LuCash, M.S., B. Farnesworth, and W.E. Winner. 2005. Response of sagebrush steppe species to $\mathrm{CO}_{2}$ and soil temperature. Western North American Naturalist 65:80-86.

McKenzie, D., Z. Gedalof, D.L. Peterson, and P. Mote. 2004. Climatic change, wildfire, and conservation. Conservation Biology 18:890-901.

Miller, R.F., and L.L. Eddleman. 2001. Spatial and temporal changes of sage grouse habitat in the sagebrush biome. Oregon Agricultural Experimental Station Technical Bulletin 151. 35 pp.

Miller, R.F., AND L.I. Shultz. 1987. Development and longevity of ephemeral and perennial leaves on Artemisia tridentata ssp. wyomingensis. Great Basin Naturalist 47:227-230.

Miller, R.F., T.J. Svejcar, and N.E. West. 1994. Implications of livestock grazing in the Intermountain Sagebrush Region: plant composition. Pages 101-146 in M. Vavra, W.A. Laycock, and R.D. Pieper, editors, Ecological implications of livestock herbivory in the West. Society for Range Management, Denver, CO.

Morris, A.N. 2001. The effects of changes in timing and amounts of precipitation on vegetation dynamics and nitrogen mineralization in a sagebrush-steppe ecosystem. Doctoral dissertation, Idaho State University, Pocatello. 98 pp. UMI 3012731.

Murray, R. 1975. Effect of Artemisia tridentata removal on mineral cycling. Doctoral dissertation, Washington State University, Pullman. 190 pp.

NaEeM, S. 2001. Complexity versus diversity. Pages 831843 in S.A. Levin, editor, Encyclopedia of biodiversity. Volume 1. Academic Press, San Diego, CA.

Neitlich, P., P. Rogers, and R. Rosentreter. 2003. Lichen communities indicator results from Idaho: baseline sampling. General Technical Report RMRSGTR-103, USDA Forest Service, Rocky Mountain Research Station. 14 pp.

NobLe, I.R. 1977. Long-term biomass dynamics in an arid chenopod shrub community at Koonamore, South Australia. Australian Journal of Botany 25:639-653.

Norton, J.B., T.A. Monaco, J.M. Norton, D.A. Johnson, AND T.A. JonEs. 2004. Soil morphology and organic matter dynamics under cheatgrass and sagebrushsteppe plant communities. Journal of Arid Environments. 57:445-466.

PAlmer, M.A. ET AL. 2005. Ecological science and sustainability for the 21st century. Frontiers in Ecology and the Environment 3(1):4-11.

Passey, H.B., AND V.K. HugIE. 1963. Fluctuating herbage production on an ungrazed Sierozem soil in Idaho. Journal of Soil and Water Conservation 18:8-11.

Passey, H.B., V.K. Hugie, E.W. Williams, and D.E. Ball. 1982. Relationships between soil, plant community and climate on rangelands of the Intermountain West. USDA Technical Bulletin No. 1669. 123 pp.
Pechanec, J.F., G.D. Pickford, and G. Stewart. 1937. Effects of the 1934 drought on native vegetation of the Upper Snake River Plains, Idaho. Ecology 18: 490-505.

Pechanec, J.F., and G. Stewart. 1941. Sagebrush-grass range sampling studies: variability of native vegetation and sampling error. American Society of Agronomy Journal 32:669-682.

Pearson, L.C. 1965. Primary production in grazed and ungrazed desert communities of eastern Idaho. Ecology 46:278-283.

1966. Primary productivity in a northern desert area. Oikos 15:211-228.

Peterson, D.L., AND P.J. Flowers. 1984. Estimating post fire changes in production and value of Northern Rocky Mountain-Intermountain rangelands. Research Paper PSW-173, USDA Forest Service, Pacific Southwest Forest and Range Experiment Station, Berkeley, CA. 19 pp.

PICKETT, S.T.A. 1989. Space-for-time substitution as an alternative to long-term studies. Pages 110-156 in G.E. Likens, editor, Long-term studies in ecology: approaches and alternatives. Springer-Verlag, New York.

Pokorny, M.L., R.L. Sheley, T.J. SvejCar, AND R.E. Eagel. 2004. Plant species diversity in a grassland plant community: evidence for forbs as a critical management consideration. Western North American Naturalist 64:219-230

Rabotnov, T.A. 1974. Differences between fluctuations and successions. Pages 19-24 in R. Knapp, editor, Vegetation dynamics. Handbook of vegetation science. Volume 8. W. Junk, The Hague, Netherlands.

Reeves, M.C., J.C. Winslow, And S.W. RunNing. 2001. Mapping weekly rangeland vegetation productivity using MODIS algorithms. Journal of Range Management 54:207.

Robertson, J.H., AND C.K. Pearse. 1945. Range reseeding and the closed community. Northwest Science 19:125-126.

Rowlands, P.G., AND N.J. BRIAn. 2001. Fishtail Mesa: a vegetation resurvey of a relict area in Grand Canyon National Park, Arizona. Western North American Naturalist 61:159-181.

RumsEY, W.B. 1971. Range seedings versus climax vegetation on three sites in Idaho. Journal of Range Management 24:447-450.

RYAN, K.C. 1991. Vegetation and wildland fire: implications of global climate change. Environment International 17:169-178.

SINGER, FJ. 1995. Effects of grazing by ungulates on upland bunchgrass communities of the northern winter range of Yellowstone National Park. Northwest Science 69:191-203.

Singer, FJ., AND R.A. REnKin. 1995. Effects of browsing by native ungulates on the shrubs in big sagebrush communities in Yellowstone National Park. Great Basin Naturalist 55:201-212.

Singer, F.J., AND K.A. SCHOENECKER. 2003. Do ungulates accelerate or decelerate nitrogen cycling? Forest Ecology and Management 181:189-204.

Smith, J.B., R. Richels, And B. Miller. 2001. Potential consequences of climate variability and change for the western United States. Pages 219-245 in National Assessment Synthesis Team, editors, Climate change impacts on the United States. Cambridge University Press, New York. 
SNEvA, F. 1989. Supplement to SB 659: adjusting and forecasting herbage yields in the Intermountain Big Sagebrush Region of the Steppe Province. Oregon Agricultural Experiment Station, Bulletin 673. 33 pp.

Sneva, F.A., AND C.M. BRitTon. 1983. Adjusting and forecasting herbage yields in the Intermountain Big Sagebrush Region of the Steppe Province. Oregon Agricultural Experiment Station, Bulletin 659.

SNEva, F.A., AND D.N. Hyder. 1962. Estimating herbage production on semiarid ranges in the Intermountain Region. Journal Range Management 15:88-93.

Steffen, W., A. Sanderson, P.D. Tyson, J. Jager, P.A. Matson, B. Moore, III, E. Oldfield, Et AL. 2004. Global change and the earth system: a planet under pressure. Springer-Verlag, Heidelberg.

Thomas, D.A., AND V.R. SQuires. 1991. Available soil moisture as a basis for land capability assessment in semi-arid regions. Vegetatio 91:183-189.

Tisdale, E.W., M. HironaKa, and M.A. Fosberg. 1965. An area of pristine vegetation in Craters of the Moon National Monument, Idaho. Ecology 46:349-352.

Trenberth, K., And T.J. Hoar. 1996. The 1990-1995 El Niño southern oscillation event: longest on record. Geophysical Research Letters 23:57-60.

Tueller, P.T., AND J.D. Tower. 1979. Vegetation stagnation in three-phase big game exclosures. Journal of Range Management 32:258-263.

Wagner, F.H., EDITOR. 2003. Preparing for a changing climate. The potential consequences of climate variability and change, Rocky Mountains, Great Basin. U.S. Global Change Research Program, Utah State University, Logan. 240 pp.

Wallace, A., AND D.L. Nelson. 1990. Wildland shrub die-offs following excessively wet periods: a synthesis. Pages 81-83 in E.D. McArthur et al., compilers, Proceedings-symposium on cheatgrass invasion, shrub die-off and other aspects of shrub biology and management. General Technical Report INT-276, USDA Forest Service, Intermountain Research Station.

Washington-Allen, R.A., R.D. Ramsey, and N.E. West. 2004. Spatiotemporal mapping of the dry season vegetation response of sagebrush steppe. Community Ecology 5:69-79.

WeLCH, B.L. 2005. Big sagebrush: a sea fragmented into lakes, ponds, and puddles. General Technical Report
RMRS-GTR-144, USDA Forest Service, Rocky Mountain Research Station, Fort Collins, CO. 210 pp.

Welch, B.L., AND C. Criddle. 2003. Countering misinformation concerning big sagebrush. Research Paper RMRS-RP-40, USDA Forest Service, Rocky Mountain Research Station. 28 pp.

WEST, N.E. 1983. Western Intermountain sagebrush steppe. Pages 351-374 in N.E. West, editor, Temperate deserts and semi-deserts. Elsevier, Amsterdam.

1991. Nutrient cycling in soils of semiarid and arid regions. Pages 295-232 in J. Skujins, editor, Semiarid lands and deserts: soil resource and rehabilitation. Marcel Dekker, New York.

1999. Managing for biodiversity of rangelands. Pages 101-126 in W.A. Collins and C.Q. Qualset, editors, Biodiversity in agroecosystems. CRC Press, Boca Raton, FL.

2000. Synecology and disturbance regimes of sagebrush steppe ecosystems. Pages 15-26 in P.G. Entwistle, A.M. DeBolt, J.H. Kaltenecker, and K. Steenhof, compilers, Proceedings: sagebrush steppe ecosystems symposium. Publication No. BLM/ID/ PT-0011001+1150, Bureau of Land Management, Boise, ID.

West, N.E., and T.J. Hatton. 1990. Relative influence of observer and plot randomization on detection of vegetation change. Coenoses 5:45-49.

West, N.E., AND J.A. Young. 2000. Intermountain lowlands. Pages 255-284 in M.A. Barbour and W.D. Billings, editors, North American terrestrial vegetation. 2nd edition, Cambridge University Press, New York.

Wiegand, T., and S.J. Milton. 1996. Vegetation change in semi-arid communities. Vegetatio 125:169-183.

Wilhite, D.A., AND M.H. GLanTz. 1985. Understanding the drought phenomenon: the role of definitions. Water International 10:111-120.

Wisdom, M.J., M.M. Rowland, and L.H. Suring, EDITORs. 2005. Habitat threats in the sagebrush ecosystem. Allen Press, Lawrence, KS. 383 pp.

Wu, J., AND O.L. LOUCKS. 1995. From balance of nature to hierarchical patch dynamics: a paradigm shift in ecology. Quarterly Review of Biology 70:439-466.

Received 23 May 2005 Accepted 6 July 2006 